\title{
The genus Mauritanica O. Boettger, 1879 (Gastropoda Sty- lommatophora Clausiliidae) in Tunisia
}

\author{
Ignazio Sparacio', Fabio Liberto² \& Tommaso La Mantia ${ }^{3}$
}

1Via Principe di Paternò 3, 90144 Palermo, Italy; e-mail: edizionidanaus@gmail.com

${ }^{2}$ Via del Giubileo Magno 93, 90015 Cefalù, Italy; e-mail: fabioliberto@yahoo.it

${ }^{3}$ Università degli Studi di Palermo, Dipartimento SAAF, Viale delle Scienze ed. 4, 90128 Palermo, Italy; e-mail: tommaso. lamantia@unipa.it

ABSTRACT

Currently, the genus Mauritanica O. Boettger, 1879 (Gastropoda Stylommatophora Clausiliidae) is widespread in north-eastern Algeria and central-northern Tunisia with six taxa. The taxonomic position of this genus has often been interpreted differently and the relationship with other similar genera, in particular with Siciliaria Vest, 1867, still remains to be clarified. In this paper, we provide a further contribution to the knowledge of Mauritanica by analyzing morphologically (shell, genitalia, and the type museum material) all the known Tunisian populations. In particular, the geographical spread and taxonomy of $M$. tristrami s.l. (L. Pfeiffer, 1861), M. philora s.1. (Letourneux, 1887), M. perinni polygyra (O. Boettger, 1879), and $M$. cossoni (Letourneux, 1887) are redefined. Mauritanica perinni zaghouanica (Letourneux, 1887 ) could be a valid taxon. $M$. tristrami zribensis n. ssp., $M$. tristrami nouirasaidi $\mathrm{n}$. ssp. and $M$. philora bognanii $\mathrm{n}$. ssp. are described.

KEY WORDS Door snails; Nord-Africa; taxonomy; new taxa; biodiversity.

Received 22.11.2020; accepted 09.01.2020; published online 26.03.2020

\section{INTRODUCTION}

The genus Mauritanica O. Boettger, 1879 (Gastropoda Stylommatophora Clausiliidae) is widespread in north-eastern Algeria and central-northern Tunisia with six taxa: $M$. tristrami tristrami (L. Pfeiffer, 1861), M. tristrami philora (Letourneux, 1887), M. numidica (Letourneux, 1870), M. perinni perinni (Bourguignat, 1876), M. perinni polygyra (O. Boettger, 1879), and M. cossoni (Letourneux, 1887).

Mauritanica was almost always considered a subgenus of Delima Hartmann, 1842 (Wagner, 1919; Kennard \& Woodward, 1923; Lindholm, 1924) or Charpenteria Stabile, 1864 (Nordsieck, 2002, 2007; Bank \& Neubert, 2019 with notes).
Schileyko (2000) provides a detailed description of Mauritanica, however not corresponding to morphology of all known populations of this genus, Tunisian in particular: "Shell slender, fusiform, rather thin, of 13-15 nearly flat whorls. Basal keel weak, rounded. Color reddish, chestnut or corneous-bluish; ribs white. Postembryonic whorls finely, accurately ribbed. Aperture rounded-subquadrangular, with a little reflexed, somewhat thickened margins. Superior lamella short, its inner end located deeper than external end of spiral lamella. Inferior lamella not strong, deeply lying. Subcolumellar lamella absent. Principal plica starting on right side. Lunella rightdorsal, broad, callouse. Upper palatal plica rudimentary or wanting. Height 18-26, diam. 4.0-5.5 mm (20.1 x $4.3 \mathrm{~mm}) "$. 
Nordsieck (2002), considering Mauritanica subgenus of Charpenteria, speculates that Mauritanica species and $C$. paestana may belong to a monophiletic group. Charpenteria and Mauritanica would be similar for the reduction of the anterior palatal plicae and for the penial pseudopapilla relatevely long. In the same work, Nordsieck (2002) classified the species of this subgenus into two groups: numidica group (shell with sutural papillae) and tristrami group (shell with withe surface layer).

Subsequently, Nordsieck (2013a, b) proposed Mauritanica as a subgenus of Siciliaria Vest, 1867 based on preliminary molecular data (Scheel \& Hausdorf, 2012; Uit de Weerd \& Gittenberger, 2013) and on some common morphological characters such as the presence, in the genital organs, of a thickening in the passage from the penis to the epiphallus (missing in Charpentieria) and for an indistinct delimitation between proximal and distal penis (distinct in Charpentieria).

From what has been summarized above, the taxonomic position of Mauritanica remains questionable, also because most of these taxa are not well known. Only $M$. tristrami has recently been redescribed (Sparacio et al., 2019).

In this work, we will provide a further contribution to the knowledge of Mauritanica analyzing morphologically (shell and genitalia) all the known Tunisian populations.

\section{MATERIAL AND METHODS}

Numerous localities in Tunisia have been sampled. They are mentioned, described, illustrated and summarized in a map, below. Empty shells and live specimens were collected in the field on sight on the soil and under the rocks. Observations on ecology of these organisms were made directly in the field. The shells have been immersed for less than two minutes in a solution with $60 \%$ of water $(\mathrm{H} 2 \mathrm{O})$ and $40 \%$ of $\mathrm{NaClO}$, and sub-sequently cleaned with water and a flattipped and hard bristles paintbrush. Dry shells have been studied regarding size, colour, morphology, sculpture, aperture, plicae and lamellae, lunella and clausilium. In order to study and illustrate genital organs, some specimens were put in water and fixed in $80 \%$ ethanol. The bodies were isolated from the shells and dissected under the Optika stereomicroscope using a very fine pointed scalpel, scissors and needles. Photos were taken with a Canon EOS 100D camera. Height and maximum diameter of the shell along with some parts of genitalia were measured (in millimeters) by a digital gauge.

Taxonomical references are based on the checklist of the land and freshwater Gastropoda of Europe (Bank, 2017; Bank \& Neubert, 2019).

In the shell description, apertural elements are defined: plicae or lamellae if they consist of elongated spiral structures situated in the palatum or parietum and columella respectively. The part of the cervix beside the basal keel is called cervical swelling or, if more distinct, dorsal keel. For the lower palatal plica (basalis plica) the following terms are used: posterior part $=$ subclaustralis, anterior part $=$ basalis. In the anatomical description, proximal denotes the part which is closer to the gonad and distal the part which is closer to the gonopore. The proximal female genitalia, sometimes indicated in the tables, are not described because they are not informative.

The materials used for this study are deposited in the following Museums and private collections: Faculté des Sciences, Université de Tunis, Tunisia (SUT); F. Liberto collection, Cefalù, Italy (CL); Museo Civico di Storia Naturale di Genova "G. Doria”, Italy (MSNG); Museo Civico di Zoologia, Rome, Italy (MCZR); Muséum d'Histoire Naturelle de Genève, Switzerland (MHNG); Natural History Museum University of Florence Zoological Section "La Specola", Florence, Italy (MZUF); I. Sparacio collection, Palermo, Italy (CS).

ABBREVIATIONS AND ACRONYMS. A: atrium; AG: albumen gland; $\mathrm{BC}$ : bursa copulatrix; BCD: duct of bursa copulatrix; BP: basalis plica (=lower palatal plica); BCM: branch of the columellar muscle; CD: copulatory duct; CL: columellar lamella; DBC: diverticulum of bursa copulatrix; E: epiphallus; FO: free oviduct; G: penial pseudopapilla; L: lunella; LO: left ommatophore; P: penis; PL: parietal lamella; PP: principal plica; PR: penial retractor muscle; PUPP: posterior upper palatal plica; SCL: subcolumellar lamella; SCP: subclaustralis; SL: spiral lamella; SP: sutural plica; UOS: uterine ovispermiduct; V: vagina; VD: vas deferens.

D: shell maximum diameter; ex/x: specimen/s; $\mathrm{H}$ : shell height; leg.: legit; m: meter/s; mm: millimeter/s; R2: ribs number on $2 \mathrm{~mm}$ of the penultimate whorl; sh: shell/s; s.l.: sensu lato; s. str.: sensu stricto. 


\section{RESULTS}

\section{Systematics}

Phylum MOLLUSCA Cuvier, 1795

Classis GASTROPODA Cuvier, 1795

Ordo STYLOMMATOPHORA A. Schmidt, 1855

Superfamilia CLAUSILIOIDEA Gray, 1855

Familia CLAUSILIIDAE Gray, 1855

Subfamilia ALOPIINAE A.J. Wagner, 1913

Tribù DELIMINI R. Brandt, 1956

Genus Mauritanica O. Boettger, 1879

Type species: Clausilia tristrami L. Pfeiffer, 1861

Mauritanica tristrami tristrami (L. Pfeiffer, 1861) - Figs. 1-18, 82

Clausilia tristrami - L. Pfeiffer, 1861: 140 - locus typicus: "Interior of Tunis"

Clausilia tristrami - Küster in Martini \& Chemnitz, 1861: 307, tav. 35, figs. 1-3 - im Inner von Tunis

Clausilia tristami - Bourguignat, 1864: 71-73, tav. 5, figs. 4-6 - versant méridional de l'Atlas, dans l'interieur de la régence de Tunis

Clausilia tristami - Bourguignat, 1868: 29-30 alentours de Tunis

Clausilia tristrami - Westerlund, 1878: 169-170 Mons Atlas, Tunis

Mauritanica tristrami - Boettger in Kobelt, 1879: 153, tav. 178, fig. 1800 - Atlas in Tunisien

Clausilia belluccii - Issel, 1880: 278-279 - Monte Resas (Fig. 2)

Clauslia tristami - Hagenmuller, 1884: 211 Tunisie

Clausilia tristrami - Westerlund, 1884: 73 - Tunis

Clausilia bonneti - Letourneux in Letourneux \& Bourguignat, 1887: 111 - Djebel Bou-Kourneïn

Clausilia tristami - Letourneux \& Bourguignat, 1887: 111-112 - Djebel Resas, Djebel BouKourneïn

Clausilia belluccii - Letourneux \& Bourguignat, 1887: 112 - Djebel Resas, Zaghouan, Hammam Zeriba dans l'Enfida, Djebel Bou-Kourneïn, Oued-el-Hammam près Tunis

Clausilia philora - Letourneux in Letourneux \& Bourguignat, 1887: 112-113

Clausilia (Mauritanica) tristrami - Westerlund, 1890: 116 - Tunesien
Clausilia tristrami - Westerlund, 1901: 71 - Tunesia Delima (Mauritanica) tristrami - Wagner, 1919: 132 - Tunis

Delima (Lampedusa) tristrami - Kennard \& Woodward, 1923: 307

Delima (Lampedusa) tristrami - Lindholm, 1924: 58

Papellifera bidens [not Linné 1758] - Ktari \& Rezig, 1976: tav. 8, figs. 3-4 - Zaghouan

Mauritanica tristrami - Nordsieck, 1979: 260

Mauritanica tristrami - Schileyko, 2000: 668, fig. 878

Charpenteria (Mauritanica) tristrami - Nordsieck, 2001: 20

Charpenteria (Mauritanica) tristrami tristrami Nordsieck, 2002: 27, 29, 30 35, 36, fig. 3.

Charpenteria (Mauritanica) tristrami tristrami Nordsieck, 2007: 54

Charpenteria (Mauritanica) tristrami tristrami Abbès, 2012: 46, pl. 4 fig. B.

Mauritanica tristrami tristrami - Sparacio et al., 2019: 52-57, figs. 1-3 - Djebel Reças, Djebel Bou Kornine, Djebel Zaghouan

EXAMINED MATERIaL. Tunisia, Hamman el Lif., Kobelt, ex coll. Monterosato, 1 ex (MCZR-M6181) (Fig. 1). Tunisie, Nabeul, Djebel-Bou-Kournine (= Jabal Bu Qarnayn), près de Hammam Lif collection Bourguignat G 16 - Clausilia bonneti Letourneux in Letourneux \& Bourguignat, 1887, syntype, MHNG-MOLL-108060 (Fig. 3). Tunisia, Djebel Boukornine, 8.IV.2014, 1 ex, leg. I. Sparacio (CS 4009/1); Djebel Zaghouan, 14.V.1987, 2 exx, leg. I. Sparacio (CS 3158/2); idem, 8.IV.2014, 6 exx, leg. I. Sparacio (CS 4010/6) (Figs. 4-14, 18); Djebel Reças, Mornag, 36³6'57.3”N $10^{\circ} 20^{\prime} 12.4$ 'E, 17.III.2018, 46 exx, leg. I. Sparacio (CS 4446/46); idem, 6 exx (CL T401-T406) (Fig. 4); Jebel Ressas, in hole on limestone wall, ante 2014, ex coll. M. Calò, 1 ex (CL T422).

DESCRIPTION. Shell sinistral, fusiform elongated, with 15-16.5 slightly convex whorls, reddish or reddish-gray with white ribs; apical whorls almost cylindrical, consisting of two smooth and rounded embryonal whols, the 3-5 postembryonal whorls with sparse and scarcely high ribs; subsequent whorls almost flat, with more robust and close ribs, slightly oblique, R2: 7-9; H: 22-26 mm (mean 24 $\mathrm{mm}$ ), D: $4.0-4.6 \mathrm{~mm}$ (mean $4.3 \mathrm{~mm}$ ); suture moderately deep; closed umbilicus; basal keel distinct, 
cervical swelling weak; subsquared-rounded aperture, reflex peristome, fused above on the last whorl.

On palatum (Figs. 6,8 ) there are: a thin sutural plica, the principal plica well developed, which protrudes slightly beyond the lunella, upper palatal plica developed only in the posterior portion, lunella distinct, in dorsolateral position, rudimentary subclaustralis plica merged with the base of the lunella.

On parietum (Figs. 7, 9), starting from the suture, there are: a raised parietal lamella that reaches or slightly surpasses the spiral lamella, the latter is marked and progressively decreases in height towards the aperture, columellar lamella high within, subcolumellar lamella visible in frontal view, not reaching the internal peristome border.

Clausilium (Fig. 10) plough-like with sub-rectangular basal plate, slightly emarginated, roudend sutural angle and straight columellar edge.

Genitalia (Figs. 11-14). Distal genitalia consist of vagina $(1.8-2 \mathrm{~mm})$ uniform in diameter throughout its length, bursa copulatrix complex consist of robust copulatory duct, slightly longer than the vagina $(2.8 \mathrm{~mm})$, branched in a diverticulum of the bursa copulatrix $(4 \mathrm{~mm})$, and a shorter and cylindrical bursa copulatrix duct, the separation between bursa copulatrix and its duct is hardly recognizable (bursa copulatrix duct+bursa copulatrix $3 \mathrm{~mm}$ ); short and robust free oviduct; vas deferent long and slender, entering the apical portion of epiphallus; epiphallus $(3 \mathrm{~mm})$ divided by point of insertion of robust penial retractor muscle into fusiform proximal portion, and conic distal portion with thickening at the transition epiphallus-penis. Penis (1.8 $\mathrm{mm}$ ) slightly wider than epiphallus and gradually narrows towards the genital atrium. Penial pseudopapilla well developed and rounded at the apex. Inner wall of the vagina with thin longitudinal pleats.

Body. Animal slim, elongated, posteriorly pointed, black in color, with short tentacles (Fig. 18).

Distribution AND Biology. North-eastern Tunisia, in the limestone mountain ranges south of Tunis: Djebel Reças (Figs. 15-17), Djebel Bou Kornine, Djebel Zaghouan.

It lives on rocks and limestone walls, under stones and in the soil at the base of them.

REMARKS. Mauritanica tristrami was described by Pfeiffer (1861) from "Southern slope of the Atlas, interior of Tunis".

Bourguignat (1864) hypothesizes the presence of this species in Algeria ("province de Constantine, vers les frontières tunisiennes") but, currently, there is no reliable data on the presence of $M$. tristrami in Algeria.

"Clausilia" bellucci (locus typicus, Issel, 1880: "Monte Resas; non comune, nel terriccio a piedi delle rocce, sopra la miniera di galena") and "Clausilia" bonneti (locus typicus, Letourneux \& Bourguignat, 1887: "Djebel Bou-Kournë̈n") are synonyms of $M$. tristrami tristrami.

The examined population of $M$. tristrami tristrami from Djebel Reças, Djebel Bou Kornine, and Djebel Zaghouan do not show substantial morphological and anatomical differences between them.

Mauritanica tristrami zribensis $\mathrm{n}$. ssp. - Figs. 19-25, 33, 34, 82 - http://zoobank.org/f6065 e23-977b-4925-9a18-b0e94fdb349d

Clausilia belluccii - Letourneux \& Bourguignat, 1887: 112 - Djebel Resas, Zaghouan, Hammam Zeriba dans l'Enfida, Djebel Bou-Kourneïn, Oued-el-Hammam près Tunis [partim, not Issel, 1880]

EXAMINED MATERIAL. Tunisia, Hammam Zriba surrondings, 7.V.1992, 1 paratype, leg. I. Sparacio (CS 3275/1) (Fig. 20); Hammam Zriba, $36^{\circ} 20^{\prime} 27.5^{\prime \prime} \mathrm{N} 10^{\circ} 12^{\prime} 00.2^{\prime \prime} \mathrm{E}, 27 . \mathrm{IX} .2019,30 \mathrm{exx}$, leg. I. Sparacio (CS 5069/32) (Figs. 21-25, 34); idem, holotype (Fig. 19) (MSNG); idem 1 paratype (MHNG); idem, 1 paratype (MCZR-M-TYPE 00252); idem, 4 paratypes (CL T425-T428).

DESCRIPTION OF THE HOLOTYPE. Shell sinistral, elongated, with $16^{1 / 2}$ whorls; $\mathrm{H}: 26 \mathrm{~mm}$, D: $4.4 \mathrm{~mm}$ (Fig. 19); the apical and subapical whorls are convex with very minute and just raised ribs; the following 5 whorls are yellowish in colour, the following ones are brownish-gray in colour with white ribs; R2: 8; except the apical whorls the following ones are flat, the last three subparalles to the sides, sutures indistict; basal and dorsal keels distinct, separated by an evident furrow; last whorl concave in the cervical area; aperture short, about $1 / 6$ of shell height.

On palatum there are: a sutural plica, a raised principal plica protruding beyond the lunella, upper 
palatal plica developed only in the posterior portion, lunella lateral, weak, broadened below $=$ rudimentary subclaustralis.

On parietum, starting from the suture, there are: a parietal lamella that surpasses spiral lamella, the latter is well marked and gradually decreases in height towards the aperture, columellar lamella marked and just reaching the columellar edge, subcolumellar lamella not reaching the internal border of peristome, visible in front view.

Clausilium plough-like with sub-rectangular basal plate, sutural angle slightly bent up, convex palatal edge, straight columellar edge.

Genitalia. Distal genitalia similar to that of nominotypical subspecies, distinguished by slightly longer penis $(3.1 \mathrm{~mm})$ and vagina $(2.6 \mathrm{~mm})$ shorter copulatory duct $(1.8 \mathrm{~mm})$ and slightly longer diverticulum of the bursa copulatrix $(6 \mathrm{~mm})$, and bursa copulatrix duct + bursa copulatrix $(4 \mathrm{~mm})$.

Body. Animal as in M. tristrami tristami, blackbrown in colour with a paler band on the back; skin tubercle oval-elongated; upper tentacles rather short, cylindro-conical, with small black eyes; foot with sole paler than body (Fig. 34).

VARIABILITY. Shell elongated to very elongated; the whorls 15-16 subparalles to paralles to the sides. Shell usually not decollated with 16-17 whorls; the last whorl more or less concave in the cervical area; H: 24.5-26.5 mm; D: 4-4.4 mm; R2: 7-12; genitalia as in the holotype (Figs. 19-25).

Eтymology. The specific epithet refers to the type locality, Hamman Zriba (Tunisia).

DistriBution AND BIOLOGY. Mauritanica tristrami zribensis $\mathrm{n}$. ssp. is known only for the small limestone gorge next to the village of Zriba and the surroundings of the old mines (Fig. 33).

Hamman Zriba is one of the fault blocks of the Tunisian Jurassic range as Djebel Bou Kournine, Djebel Ressas, and Djebel Zaghouan (Tawadros, 2011).

REMARKS. Letourneux \& Bourguignat (1887) cited this population as "Clausilia belluccii" and they considered it "variété" of M. tristrami.

This new subspecies differs from M. tristrami tristrami for the shell less robust, more elongated with mean $\mathrm{H} / \mathrm{D}=6.3$ (5.4 in $M$. tristrami tristrami); greater number of whorls; central whorls flatter, with thinner and more numerous ribs; last whorl concave in lateral view; aperture shorter with mean $\mathrm{H}=4.6$ (5.02 in $M$. tristrami tristrami) and mean $\mathrm{H}$ shell/ $\mathrm{H}$ aperture $=5.76$ (4.71 in $M$. tristrami tristrami); longer basal keel and distinct dorsal keel. On palatum, the lunella is less developed and in a more lateral position; on parietum, the parietal lamella is longer; genitalia with thinner and longer diverticulum of the bursa copulatrix and shorter copulatory duct; the clausilium is more roudend.

Mauritanica tristrami nouirasaidi n. ssp. Figs. 26-32, 35, 36, 82 - http://zoobank.org/d 0066e1c-93dc-48e3-8b33-4dc82b54007f

Clausilia philora - Letourneux in Letourneux \& Bourguignat, 1887: 112 - Kessera [not Letourneux, 1887]

EXAMINED MATERIAL. Tunisia, Kesra, 7.V.1992, 1 ex, leg. I. Sparacio (CS 3280/1); Plateau de Kesra, 3548'34.89'N 922'22.45'E, 19.VII.2018, 2 paratypes, leg. G. Domina, (CS 5036/2); Kesra, 3548'32.6'N 9²2'17.3”'E, 27.IX.2019, 34 paratypes, leg. I. Sparacio (CS 5070/38) (Figs. 2732, 36); idem, holotype (Fig. 26) (MSNG); idem, 1 paratype (MZUF); idem, 1 paratype (MCZR-MTYPE 00253); idem, 4 paratypes (CL T429-T432).

DESCRIPTION OF THE HOLOTYPE. Shell sinistral, elongated, with 14 whorls slightly convex; $\mathrm{H}: 21.3$ $\mathrm{mm}$, D: $4 \mathrm{~mm}$ (Fig. 26); the apical and subapical whorls are convex and smooth; the following 5 whorls are brownish-gray in colour, the following whorls are brown in colour with white ribs; R2: 8 . Basal and dorsal keels moderatly high separated by a large furrow.

On palatum there are: a thin sutural plica, a raised principal plica protruding beyond the lunella, upper palatal plica developed only in its posterior portion, lunella dorsolateral little, raised and fused with rudimentary subclaustralis.

On parietum, starting from the suture, there are: a parietal lamella that surpasses the spiral lamella, the latter is well marked and gradually decreases in height towards the aperture, columellar lamella high, ending near to columellar edge, subcolumellar lamella higher in the outer end, ending near or on to internal border of peristome, well visible in front view.

Clausilium plough-like with sub-rectangular basal plate, and straight palatal and columellar edges. 
Genitalia. Distal genitalia similar to that of nominotypical subspecies, distinguished by penis and vagina slightly longer $(2.6 \mathrm{~mm})$, longer diverticulum of the bursa copulatrix $(6.5 \mathrm{~mm})$ and shorter penial pseudopapilla.

Body. Animal brown in colour with a paler band on the back.

VARIABILITY. Shell usually not decollated with 14-15 whorls; the apical and subapical whorls are convex and smooth or with very minute ribs; $\mathrm{H}$ : 20.5-24 mm (mean: $22.25 \mathrm{~mm}$ ), D: 4-4.5 mm (mean: $4.25 \mathrm{~mm}$ ); R2: 7-10; genitalia as in the holotype (Figs. 27-32).

ETymology. This new subspecies is dedicated to the Prof. Saïd Nouira (Tunis, Tunisia), Tunisian scholar and naturalist.

Distribution and Biology. Mauritanica tristrami nouirasaidi $\mathrm{n}$. ssp. is known only for the surroundings of Kesra (Siliana Governorate). It lives on calcareous rocks (Figs. 35, 36).

REMARKS. Little-known population, cited by Letourneux \& Bourguignat (1887: "environs de Kessera") and attributed to M. philora (see below).

This new subspecies is mostly distinguishable from the others Tunisian Mauritanica, particularly, for a developed subcolumellar lamella reaching and going beyond the internal edge of the peristome and from the other two subspecies of $M$. tristrami for the shorter shell, fewer number of whorls, moderatly high basal and dorsal keels, separated by a large furrow, for the longest diverticulum of the bursa copulatrix.

Mauritanica philora philora (Letourneux, 1887) - Figs. $37-43,51,82$

Clausilia philora - Letourneux in Letourneux \& Bourguignat, 1887: 112-113 - locus typicus: El Kef. Other mentioned locality: Kessera

Clausilia (Mauritanica) philora - Westerlund, 1890: 116 - Tunesien

Clausilia philora - Westerlund, 1901: 71 - Tunesia

Charpenteria (Mauritanica) tristrami philora Nordsieck, 2007: 54

Charpenteria (Mauritanica) tristrami philora -
Abbès, 2012: 45, pl. 4 fig. A - dans la région de Djebba

Mauritanica tristrami philora - Sparacio et al., 2019: 52, 55 - El Kef

Examined Material. Tunisie, Kef, Crêtes du $\mathrm{Kef}(=\mathrm{El}-\mathrm{Kef}=\mathrm{El} \mathrm{Kaf})$ - collection Bourguignat G 16 - Clausilia philora Letourneux in Letourneux \& Bourguignat, 1887 - syntype, MHNG-MOLL108072 (Fig. 37). Tunisia, El Kef, 13.V.1987, 4 exx, leg. I. Sparacio (CS 3154/4); idem, 2 exx (CL T206-T207); El Kef, 36 11 '45.8”'N 843'31.0”'E, 16.III.2018, 85 exx, leg. I. Sparacio (CS 4460/85) (Figs. 38-43, 51); idem, 8 exx (CL T433-T440).

DESCRIPTION. Shell fusiform, sinistral, usually not decollated with 13-14 whorls, shell decollated with 8-10 remaining whorls in adult shell; shell not decollated with obtuse apex (Fig. 38), H: 19-22.5 mm (mean: 20.75); D: 3.9-4.3 mm (mean: 4.1); the apical and subapical whorls are convex and smooth or with very minute ribs; the following 5 whorls are yellowish in colour, the remainig whorls are light brown in colour with regular and slightly elevated ribs; R2: 11-15; the space between the ribs is micro-reticulated; spire slowly and regularly growing, umbilicus closed; suture shallow; basal and dorsal keels indistinct; aperture about $1 / 5$ of shell height, ovoidal-subsquared; peristome continous, slightly thickened, reflected, superiorly attached to the wall of last whorl.

On palatum (Fig. 39) there are: a thin sutural plica, sometimes absent, a raised principal plica protruding beyond the base of the lunella, upper palatal plica developed only in the posterior portion, lunella dorsolateral, its base is fused with the well raised subclaustralis plica.

On parietum (Fig. 40), starting from the suture, there are: a parietal lamella that reaches the spiral lamella, the latter is well marked and gradually decreases in height towards the aperture, columellar lamella high within and just reaching the columellar margin, subcolumellar lamella short, generally not visible in frontal view.

Clausilium (Fig. 41) plough-like with sub-rectangular basal plate, slighlty convex palatal edge and straight columellar edge.

Genitalia (Figs. 42, 43). Genitalia are similar in size and shape a to that of $M$. tristami: vagina $(1.5-18 \mathrm{~mm})$, copulatory duct $(2.2-2.3 \mathrm{~mm})$, bursa copulatrix duct + bursa copulatrix $(3.8 \mathrm{~mm})$, diver- 
ticulum of the bursa copulatrix $(4.5-4.8 \mathrm{~mm})$; epiphallus (3-3.4 mm), penis (2.9-3.2 mm). Penial pseudopapilla conic.

Body. Animal dark brown; skin tubercle ovalelongated; upper tentacles rather short, cylindroconical, with black eyes; foot long with sole paler than body.

Distribution AND Biology. Mauritanica philora lives on the calcareous rocks in the surroundings of El Kef, northwestern Tunisia: "le type a été recueilli sur les crêtes d'El Kef, où il parait assez abondant" (Letourneux \& Bourguignat, 1887) (Fig. 51).

REMARKS. This taxon was described as a distinct species and was considered such by Westerlund, (1890; 1901).

Recently, Nordsieck (2007) considers it a subspecies of M. tristrami. Abbes (2012), following this taxonomic approach, observes that further studies would be needed to confirm this classification, considering that the two populations live in two distinct geographical areas: [M. tristrami tristrami] "aux Nord est de la Tunisie particulièrement Djbel Zaghouan et Djebel Reças alors que la deuxième [M. tristrami philora] n'a été trouvée que dans la région de Djebba située au nord ouest de la Tunisie".

Mauritanica philora philora differ from $M$. tristrami ssp. for: the shorter shell (19-22.5 $\mathrm{mm}$ in $M$. philora; $20.5-26 \mathrm{~mm}$ in $M$. tristrami), fewer whorls (13-14 in M. philora; 14-17 in M. tristrami); thinner and more numerous ribs (R2: $11-15$ in $M$. philora; R2: 7-12 in M. tristrami); subcolumellar lamella shorter generally not visible in frontal view (visible in $M$. tristrami); more developed subclaustralis.

Mauritanica philora bognannii $\mathrm{n}$. spp. - Figs. 44-50, 52-54, 82 - http://zoobank.org/f84ead 40-ddd2-4a7a-8884-bf4071d0ab5f

Charpenteria (Mauritanica) tristrami philora Abbès, 2012: 45, pl. 4 fig. A - dans la région de Djebba

EXAMINED MATERIAL. Tunisia, Teboursouk surroundings, 13.V.1987, 2 paratypes, leg. I. Sparacio (CS 3153/2); Djebba, 24.VI.2007, 3 exx, leg. I.
Abbes (SUT, see also Abbes, 2012: 46). Teboursouk, Dougga, 36 $255^{\prime} 36.0^{\prime \prime} \mathrm{N} 9^{\circ} 13^{\prime} 07.4^{\prime \prime} \mathrm{E}, 16 . \mathrm{III} .2018$, 48 paratypes, leg. I. Sparacio (CS 4461/52) (Figs. 45-50, 53-54); idem, holotype (Fig. 44) (MSNG); idem, 1 paratype (MZUF); idem, 1 paratype (MHNG); idem, 1 paratype (MCZR-M-TYPE 00254); idem, 4 paratypes (CL T441-T444).

DESCRIPTION OF HOLOTYPE. Shell fusiform, robust, with 13 convex whorls; H: $20 \mathrm{~mm}$, D: $4.1 \mathrm{~mm}$ (Fig. 44); the apical and subapical whorls are convex and smooth; the following 5 whorls are yellowish in colour, the last whorls are dark brown in colour with white ribs; R2: 16. Basal and dorsal keels slightly elevated separated by a superficial furrow.

On palatum there are: a thin sutural plica, a long and raised principal plica protruding beyond the lunella, upper palatal plica developed only in the posterior portion, lunella dorsolateral, its base is fused with the well raised subclaustralis plica.

On parietum, starting from the suture, there are: a parietal lamella that reaches or surpasses the spiral lamella, the latter is well marked and gradually decreases in height towards the aperture, columellar lamella developed and just reaching the columellar edge, subcolumellar lamella just reaching the internal peristome border, little visible in frontal view.

Clausilium plough-like with oval basal plate, sutural angle bent up, convex palatal edge and straight columellar edge.

Genitalia are similar in size and shape a to that of nominotypical subspecies, distinguished by slightly longer vagina $(1.8-2 \mathrm{~mm})$ and diverticulum of the bursa copulatrix $(5.5-5.8 \mathrm{~mm})$. Penial pseudopapilla conic.

Body. Animal similar to M. philora philora, entirely black.

VARIABILITY. Shell not decollated with 13-14 convex whorls, the last 5 whorls are yellowish in colour or dark brown; shell decollated with 7-10 whorls remainig in adult shell; shell H: 19.2-22 (mean: $20.6 \mathrm{~mm}$ ), D: $4-4.6 \mathrm{~mm}$ (mean: $4.3 \mathrm{~mm}$ ); R2: 15-20; sometimes, other thin and incomplete ribs are found next to the main ribs; genitalia as in the holotype (Figs. 45, 49, 50).

Eтymology. To Patrizia Bognanni from Palermo (Italy), artistic photographer.

Distribution AND Biology. This new subspecies lives on rocks and limestone walls, in the 
surroundings of Teboursouk, Dougga (Figs. 52-54) and Djebba, in central-northern Tunisia.

REMARKS. Mauritanica philora bognannii n. spp. differs from $M$. philora philora for the shape of the shell more robust and more wide $(\mathrm{H} / \mathrm{D}=4.95$, it is 5.2 in $M$. philora philora), the darker brown color with the most evident white wider and higher ribs, the more numerous ribs (R2: 15-20), more developed parietal and subcolumellar lamella, diverticulum of the bursa copulatrix and bursa copulatrix duct slightly longer, clausilium oval-shaped, basal and dorsal keels slightly elevated but present.

We also attribute to this new subspecies the populations of Djebba of which we have examined few specimens (cited also by Abbes, 2012, sub C. tristrami philora).

Mauritanica perinni polygyra (O. Boettger, 1879) - Figs. 56-63, 70, 82

Clausilia (Mauritanica) polygyra - Boettger in Kobelt, 1879: 153, tav. 177, fig. 1793 - Ruinen von Carthage

Clausilia (Mauritanica) polygyra - Westerlund, 1884: 73 - Tunis

Clausilia Perinnei - Letourneux \& Bourguignat, 1887: 113 - Djebel Zaghouan

Clausilia (Mauritanica) perinni - Westerlund, 1890: 116 - Alg. (Djebel Thaya u. Dj. Guerar), Tunes (Dj. Zaghouan).

Clausilia perinnei - Westerlund, 1901: 72 - Algeria, Tunesia

Charpenteria (Mauritanica) perinni polygyra Nordsieck, 2002: 27, 29, 29, 35, 36 - Djebel Zaghuan

Charpenteria (Mauritanica) perinni polygyra $(=z a-$ ghouanica) - Nordsieck, 2002: 36

Charpenteria (Mauritanica) perinni polygyra Nordsieck, 2007: 54

Charpenteria (Mauritanica) perinni polygyra Abbès, 2012: 47, pl. 4 fig. C - Djebel Zaghouan

Mauritanica perinni polygyra - Scheel \& Hausdorf, 2012: 3799, 3801

EXAMINED MATERIAL. Mauritanica perinni Letourneux, 1876: Algeria, Djebel Thaya (Clausilia perinnei Letourneux, 1876 - syntype, MHNGMOLL-108066) (Fig. 55).

Mauritanica perinni polygyra: Tunisia, Djebel Zaghouan, 14.V.1987, 2 exx, leg. I. Sparacio (CS
3159/2); SE Zaghouan, 36²3'14.1'N 1008'39.8'E, 7.V.1992, 85 exx, leg. I. Sparacio (CS 3276/85) (Figs. 56-61, 63, 70); idem, 8 exx (CL T445-T452); Djebel Zaghouan, near Hotel Les Nymphes, $36^{\circ} 23$ '21.9'” 1008'17.3'E, 8.IV.2014, 18 exx, leg. I. Sparacio (CS 4020/18); Tunisia, Djebel Zaghouan, $36^{\circ} 22^{\prime} 00^{\prime \prime} \mathrm{N}, 10^{\circ} 07^{\prime} 14^{\prime \prime} \mathrm{E}, 18$.VII.2018, 1 ex, leg. G. Domina (CS 5032/1); Djebel Zaghouan, SW Zaghouan, 36²3'14.1'N 1008'39.8'E, 30.IX.2019, 13 exx, leg. I. Sparacio (CS 5071/13).

DESCRIPTION. Shell elongated, fusiform, sinistral, robust, decollated or not; shell decollated with 9-12 whorls remaining in adult shell, shell not decollated with 15-17 little convex whorls; obtuse apex, yellowish brown protoconch and purplishbrown teleoconch, (Figs. 56, 62, 63); H (not decollate): $25-27.5 \mathrm{~mm}$; D: $4-4.9 \mathrm{~mm}$; apical and subapical whorls convex and smooth or very finely ribbed; the following whorls with very minute and just raised ribs; in the last six whorls ribs more evident and decrease in height from the base to the suture; R2: 8-11; spire slowly and regularly growing, umbilicus closed; suture shallow; basal keel little distinct, cervical swelling present; aperture about $1 / 5$ of shell height, ovoidal-subsquared; peristome continous, thickened, reflected, superiorly attached to the wall of last whorl.

On palatum (Fig. 57) there are: a sutural plica, a raised principal plica protruding beyond the lunella, upper palatal plica developed only in the posterior portion, lunella dorsolateral raised and fused with the very little subclaustralis plica.

On parietum (Fig. 58), starting from the suture, there are: a parietal lamella that surpasses the spiral lamella, the latter is well marked and gradually decreases in height towards the aperture, columellar lamella high and just reaching the columellar edge, subcolumellar lamella not reaching the internal peristome border, visible in front view.

Clausilium (Fig. 59) plough-like with sub-rectangular basal plate, convex palatal edge and straight columellar edge.

Genitalia (Figs. 60, 61). Distal genitalia are similar in size and shape to that of $M$. tristami ssp.: vagina $(2.4-2.6 \mathrm{~mm})$, copulatory duct $(3-3.4 \mathrm{~mm})$, penis (3-3.2 mm), epiphallus (3.1-3.4 mm) but distinguished by longer bursa copulatrix duct + bursa copulatrix $(5-5.2 \mathrm{~mm})$ and very longer diverticulum of the bursa copulatrix $(8.2-8.6 \mathrm{~mm})$. Penial pseudopapilla well developed, conic-elongated, 
with rounded apex. Inner wall of the vagina with thin longitudinal pleats.

Body. Animal similar to previous Mauritanica species, black, elongated; foot with sole paler than body.

Distribution AND Biology. Mauritanica perinni polygyra was described (O. Boettger, 1879) from "Ruinen von Carthage" and the figure attached to the work (O. Boettger in Kobelt, 1879; fig. 1793) really refers to this species (Fig. 62). Westerlund (1884) reports this species for "Tunis", but Letourneux \& Bourguignat (1887: sub Clausilia Perinnei) identify "Djebel Zaghouan" as the true locality of $M$. perinni polygyra in Tunisia.

It is known only from Djebel Zaghouan, where it lives on calcareous rocks, in cavities and under stones (Figs. 67-70).

Remarks. "Mauritanica" polygyra is considered a subspecies of M. perinni from Algeria (Nordsieck, 2002, 2007; Abbès, 2012), type locality "sous détritus à l'entrée d'une des cavernes du Djebel Thaya, montagne située entre Jemmapes et Gueima, dans la provincie de Costantine".

Based on original description (Bourguignat, 1876) and photographic examination of the type material (Fig. 55), M. perinni perinni is morphologically distinct from its subspecies polygyra for smaller dimensions ( $\mathrm{H}: 24 \mathrm{~mm})$, lower number of whorls (14), more robust shell, opaque and more finely striated shell surface, especially in the cervical area; larger aperture with wider and callous peristome.

Mauritanica perinni and M. polygyra could be considered two distinct species, if we also take into account their geographical isolation. However, due to the lack of greater knowledge on the morphological and anatomical variability of M. perinni, we prefer to report the two taxa according to the current systematics (see cited references).

Mauritanica perinni zaghouanica (Letourneux, 1887) - Figs. 64-66, 82

Clausilia Perinnei Var. zaghouanica - Letourneux \& Bourguignat, 1887: 113 - Djebel Zaghouan

Clausilia (Mauritanica) perinni v. zaghouanica Westerlund, 1890: 116 - Tunes (Djebel Zaghouan)
Clausilia perinnei Var. zaghouanica - Westerlund, 1901: 72 - Tunesia

Charpenteria (Mauritanica) perinni polygyra $(=z a-$ ghouanica) - Nordsieck, 2002: 36

Charpenteria (Mauritanica) perinni polygyra Abbès, 2012: 47, pl. 4 fig. C

EXAMINED MATERIAL. Tunisia, Djebel Zaghouan, (Clausilia perinnei var. zaghouanica Letourneux, 1876 - syntype, MHNG-MOLL-108070) (Fig. 65). Tunisia, Zaghouan, Oued Dalia (= Dalya, Daliya), 5.X.2008, 6 exx, leg. I. Abbes (SUT, see also Abbes, 2012 p. 47 and pl. 4 fig. C); Tunisia, Zaghouan, 1 ex (MZUF GC/61859).

DESCRIPTION. Mauritanica perinni zaghouanica (Figs. 64-66) differs from M. perinni polygyra for bigger size (H: $27.5-30 \mathrm{~mm}$, D: $4.9-5.5 \mathrm{~mm}$ ); more numerous whorls (17-18), more convex whorls 3-7; with fewer ribs (R2: 7-9) clearly visible only in the last 4 whorls; the basal and dorsal keels are distinct, separed by a large and shallow furrow. On parietum, parietal lamella does not reach the spiral lamella; subcolumellar lamella not reaching the internal peristome border, visible in front view.

Distribution AND BIOLOGY. Mauritanica perinni zaghouanica was found in south-western slope of Djebel Zaghouan.

REMARKS. Mauritanica perinni zaghouanica is little known in the malacological literature; recently, Nordsieck (2002) considered it a synonym of $M$. perinni polygyra (see also Nordsieck, 2007 and Abbès, 2012).

We have not found specimens of "zaghouanica" mixed within the populations of "polygyra". The few specimens of typical "polygyra" of greater size and with a higher number of whorls do not show the morphological characters of zaghouanica, particularly the shell more robust, more convex whorls, fewer ribs, the basal and dorsal keels distinct.

Pending further research, we prefer to consider M. perinni zaghouanica distinct at a subspecific level.

Mauritanica cossoni (Letourneux, 1887) - Figs. $71-77,80-82$

Clausilia cossoni - Letourneux in Letourneux \& 
Bourguignat, 1887: 113-114 - locus typicus: "Dans les anfractusosités des rochers, au Cap Bon"

Clausilia (Mauritanica) cossoni - Westerlund, 1890: 116 - Tunesien

Clausilia cossoni - Westerlund, 1901: 72 - Tunesia

Clausilia (Mauritanica) cossoni - Nordsieck, 2002: 29, 31, 35, fig. 5 - Cap Bon (lectotype)

Clausilia (Mauritanica) cossoni - Nordsieck, 2007: 54

Clausilia (Mauritanica) cossoni - Abbès, 2012: 45, pl. 4 fig. A - Diar el ousfen

Mauritanica cossoni - Cossignani 2014: 189 Tunisia

EXAmined material. Cape Bon peninsula, Cape Bon, 300 m, 14.V.1987, 6 exx, leg. I. Sparacio (CS 3157/6); Cape Bon, near Al Huwariyah, $37^{\circ} 03^{\prime} 45.8^{\prime \prime} \mathrm{N} 11^{\circ} 01^{\prime} 51.8^{\prime}$ 'E, 6 exx, 15.III.2018, leg. I. Sparacio (CS 4459/6); idem, 26.IX.2019, 78 exx (CS 5072/78) (Figs. 71-77, 80-82); idem, 6 exx (CL T453-T458); Cap Bou peninsula, Cap Bon, $350 \mathrm{~m}$, under stones, ante 2014, ex coll. M. Calò 1504935, 1 ex (CL T424).

DESCRIPTION. Shell elongated, fusiform, sinistral, not decollated, obtuse apex, with 11-12 convex whorls; brown or blackish-brown in colour with sutural papillae scattered and sometimes slightly evident; H: 16-19 mm; D: 3.8-4.5 mm (Figs. 71, 72); apical and subapical whorls convex and very finely ribbed, the following whorls with minute, oblique and just raised ribs sometimes incomplete or obsolete; R2: $12-15$; spire slowly and regularly growing, umbilicus closed; suture shallow; basal keel distinct, cervical swelling present, separated by a shallow furrow; aperture about 1/6 of shell height, ovoidal-subsquared; peristome white, continous, slightly thickened, reflected, superiorly attached to the wall of last whorl.

On palatum (Fig. 73) there are: a thin sutural plica, a long and raised principal plica, slightly wider in its posterior portion and protruding beyond the lunella, upper palatal plica developed only in the posterior portion, lunella dorsal or dorsolateral, raised and fused with the well developed lower palatal plica (subclaustralis + basalis).

On parietum (Fig. 74), starting from the suture, there are: a parietal lamella that reaches the internal border of peristome and with the inner extremity that surpasses the spiral lamella, the latter is well marked and gradually decreases in height towards the aperture, columellar lamella more o less high and reaching the columellar edge, subcolumellar lamella generally visible in front view, reaching the internal peristome border.

Clausilium (Fig. 75) plough-like with sub-rectangular basal plate, slightly convex palatal edge and straight columellar edge.

Genitalia (Figs. 76, 77) similar to that of other Mauritanica but distinguished by a very short vagina (1.2-1.8 mm), a very long and robust copulatory duct (4.5-5 mm), a long diverticulum of the bursa copulatrix $(5-5.3 \mathrm{~mm})$, and shorter and cylindrical duct of bursa copulatrix + bursa copulatrix $(3.5 \mathrm{~mm})$.

Penial pseudopapilla conic with pointed apex and smaller than the other Mauritanica species. Inner wall of the vagina with thin longitudinal pleats and a little annular pad in the distal part.

Body. Animal similar to other Mauritanica, relatevely long, black; foot narrow, black.

Distribution AND Biology. Mauritanica cossoni is known only from Cape Bon, north-eastern Tunisia (Figs. 78, 79).

It lives on rocks but it is common in the wet bedding of a pine forest (Pinus pinea $\mathrm{L}$.), under stones and debris (Figs. 80, 81).

REMARKS. Nordsieck (2002) selected a lectotype of $M$. cossoni, from the only syntype of the Bourguignat collection (NMG 8062, Tunisia: Cap Bon) that was available, to facilitate the study with similar species. In the same work, Nordsieck (2002) classified the Mauritanica species into two groups: tristrami group (shell with withe surface layer) including tristrami, philora, perinni, polygyra, and numidica group (shell with sutural papillae) including cossoni and numidica.

Mauritanica cossoni appears distinct from all Tunisian Mauritanica both geographically, as it lives only in the northern part of Cape Bon, the Tunisian region closest to Sicily, and morphologically for the smaller shell, with lower number of whorls, the presence of a basalis (absent in all other Mauritanica species) and for the genitalia with a short vagina and a very long copulatory duct and smaller penial pseudopapilla. For all these characters $M$. cossoni appears closer to the genus Siciliaria s. str. than to Mauritanica. However, in the absence of molecular data we prefer to maintain the current systematics. 


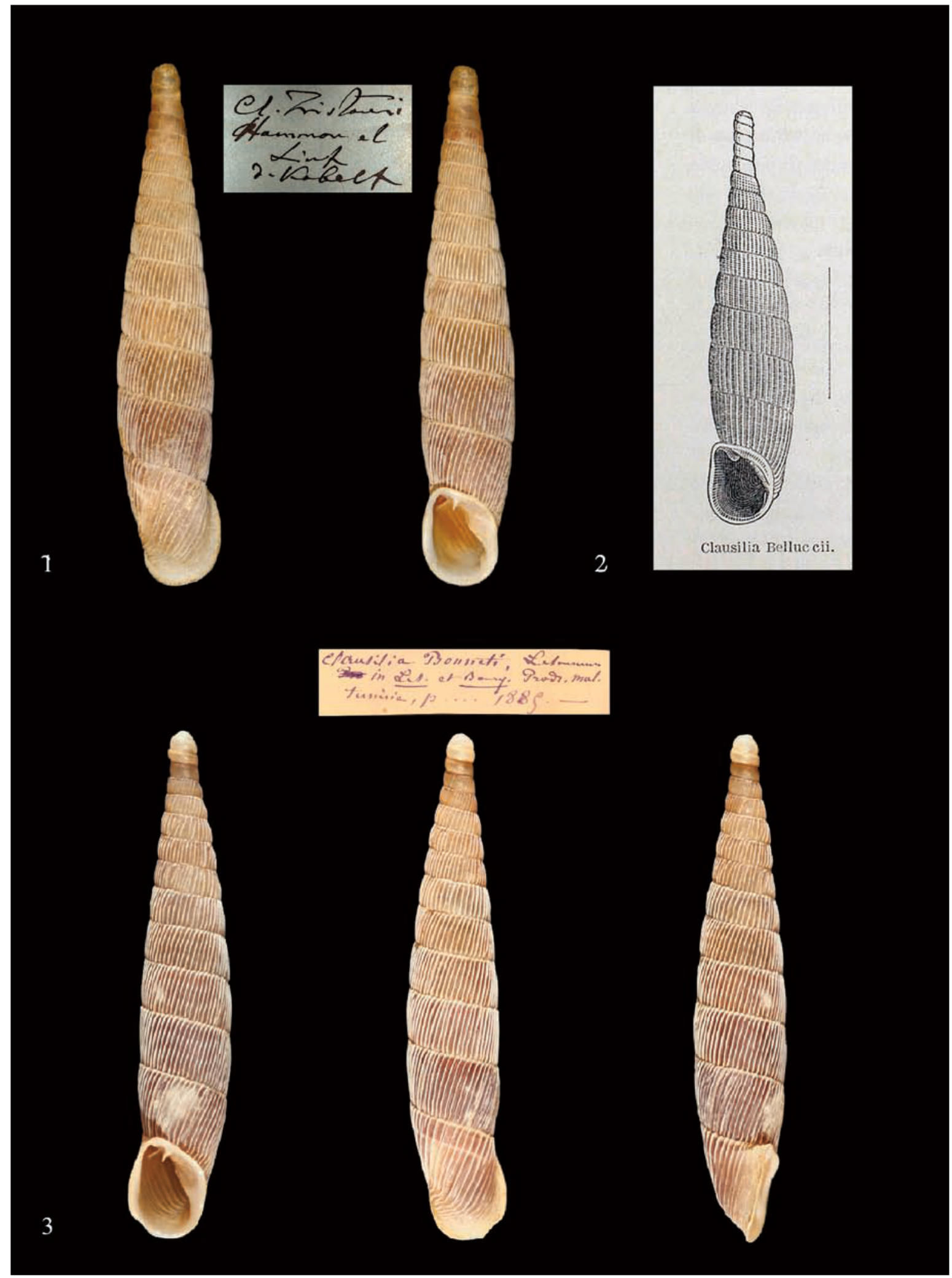

Figure 1. Mauritanica tristrami tristrami, Hamman el Lif, ex coll. Monterosato ( $\mathrm{H}=24 \mathrm{~mm})$, with original label. Figure 2. Clausilia belluccii by Issel, 1880 p. 278. Figure 3. Clausilia bonneti Letourneux 1887, Djebel-Bou-Kournine, syntype, with original label $(\mathrm{H}=23.4 \mathrm{~mm})$. 


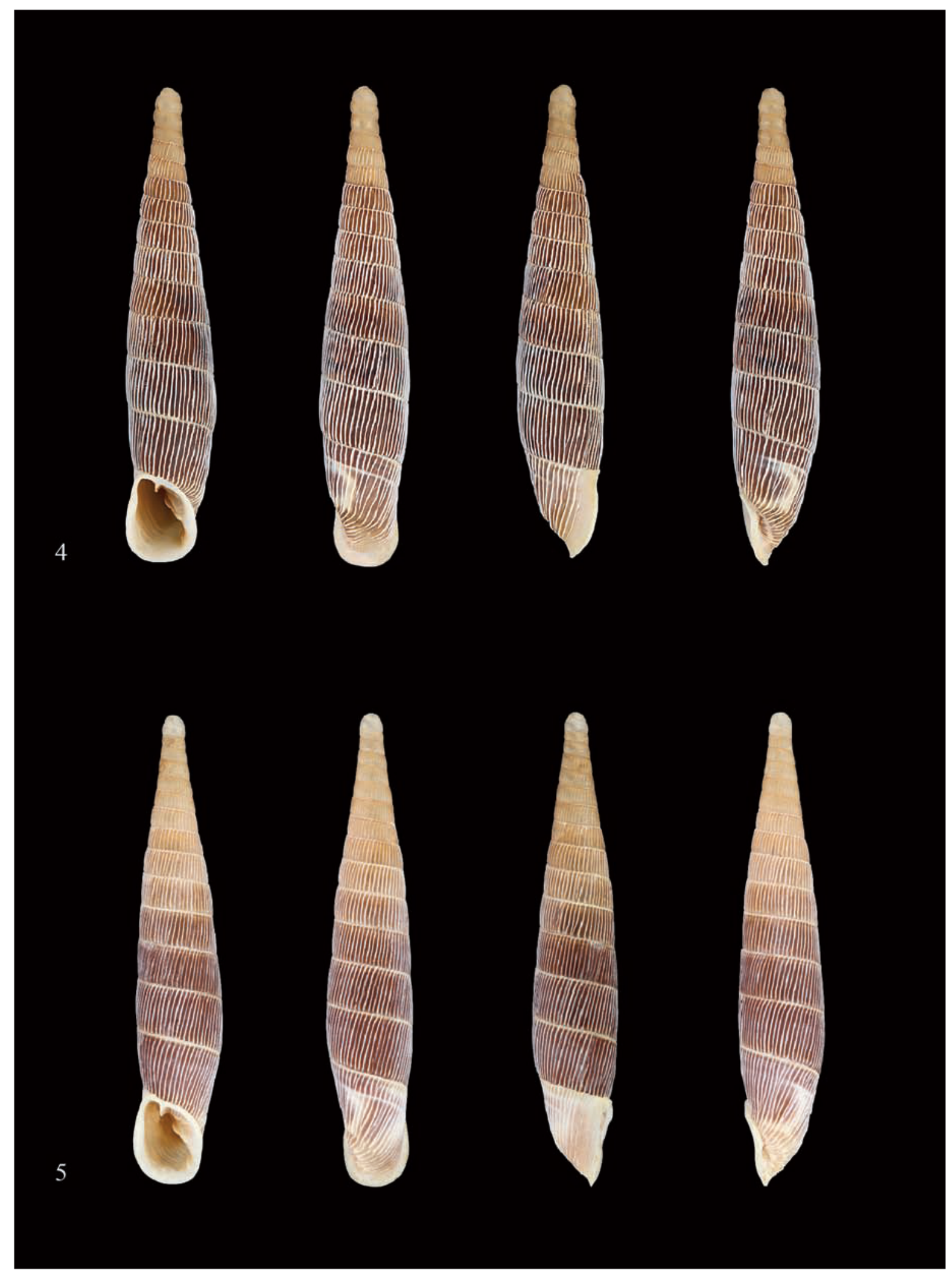

Figure 4. Mauritanica tristrami tristrami, Djebel Reças: Mornag, $\mathrm{H}=24.5 \mathrm{~mm}$. Figure 5. Mauritanica tristrami tristrami, Djebel Zaghouan, $\mathrm{H}=24.2 \mathrm{~mm}$. 


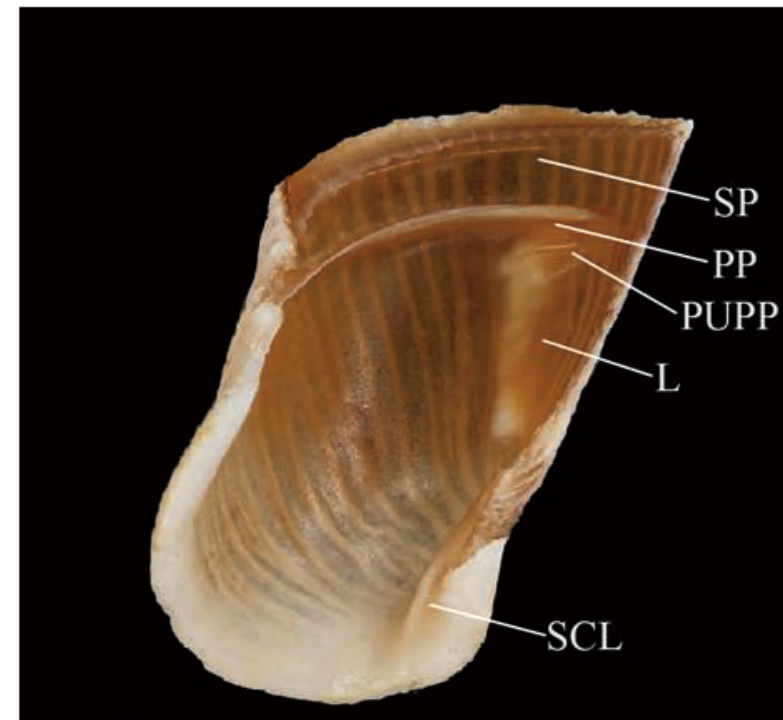

6

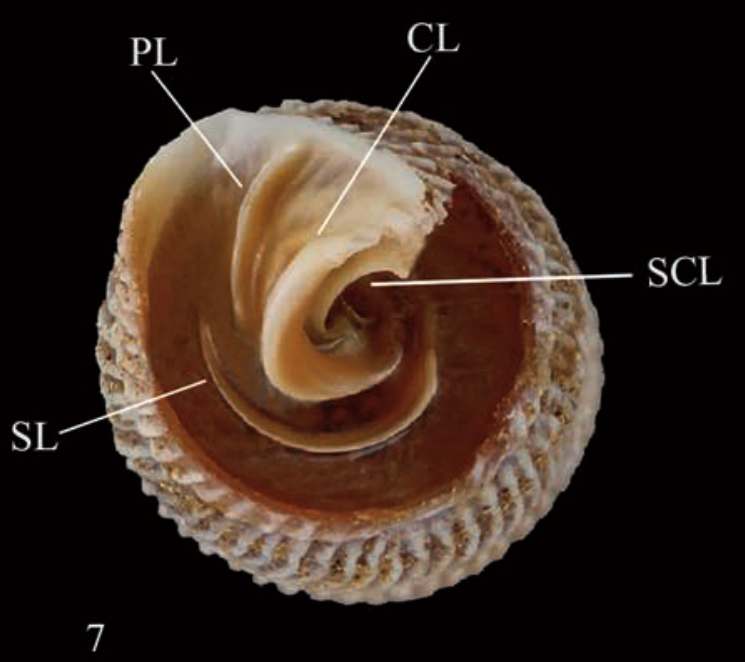

8
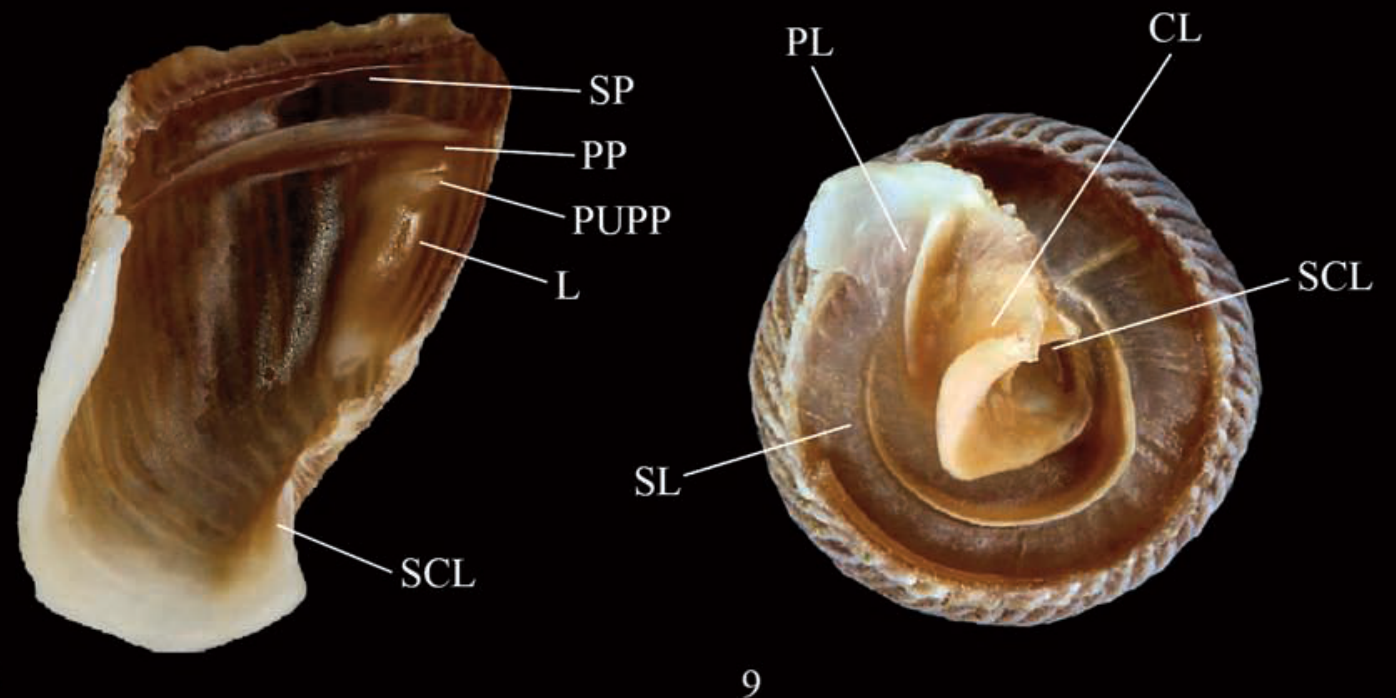

10

$2 \mathrm{~mm}$

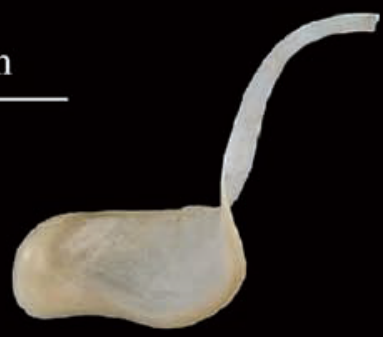

Figures 6-10. Mauritanica tristrami tristrami, Djebel Reças: Mornag. Fig. 6: palatum. Fig. 7: parietum. Fig. 8: palatum. Fig. 9: parietum. Fig. 10: clausilium. 


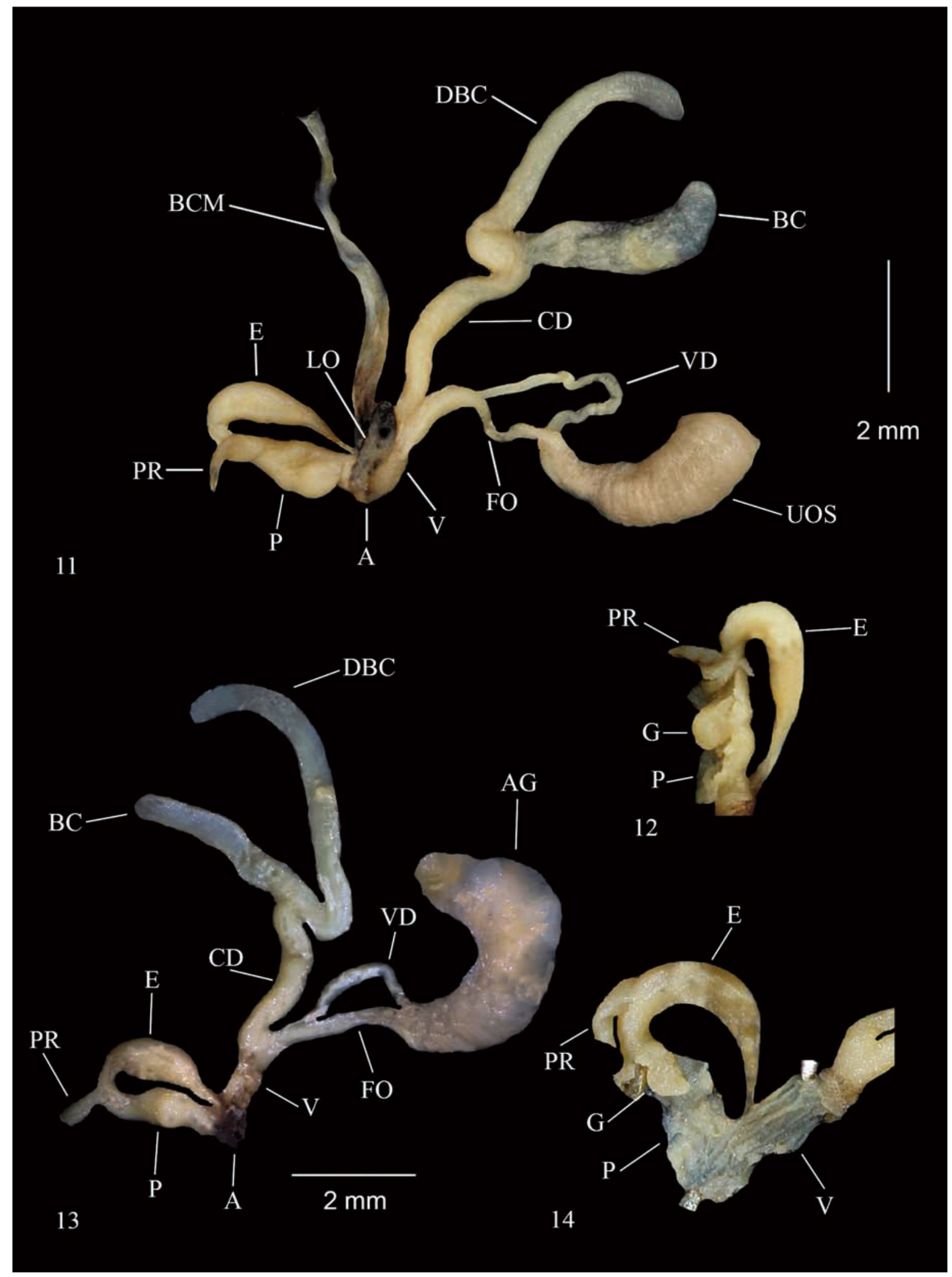

Figures 11-14. Mauritanica tristrami tristrami, Djebel Reças: Mornag. Fig. 11: genitalia.

Fig. 12: inner structures of the penis. Fig. 13: genitalia. Fig. 14: inner structures of the penis and vagina. 

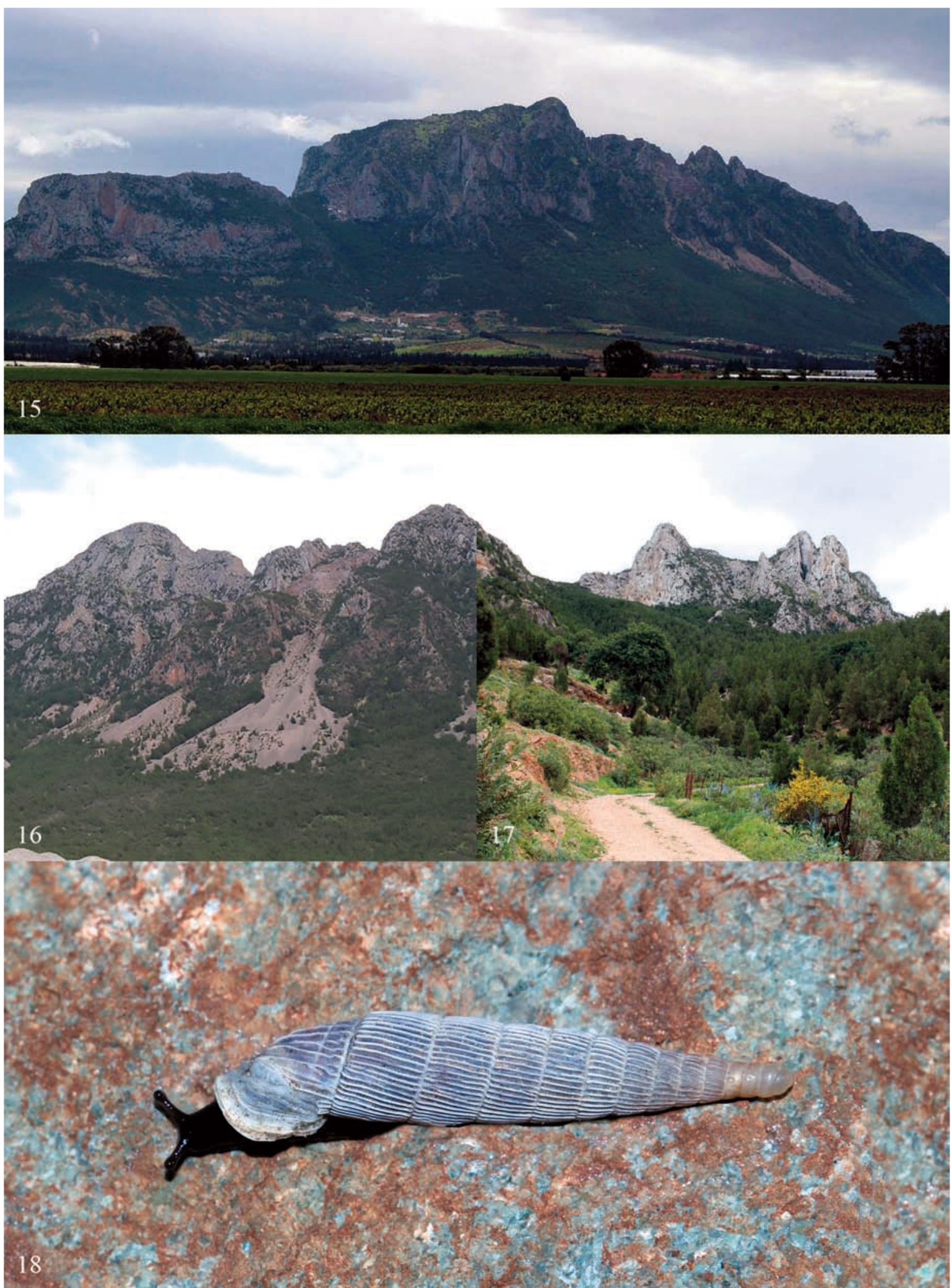

Figures 15, 16. Tunisia, landscapes of Djebel Reças. Figure 17. Djebel Reças, Mornag. Figure 18. Idem, Mauritanica tristrami tristrami. 
326

IgNAZIO SPARACIO Et AUI

19
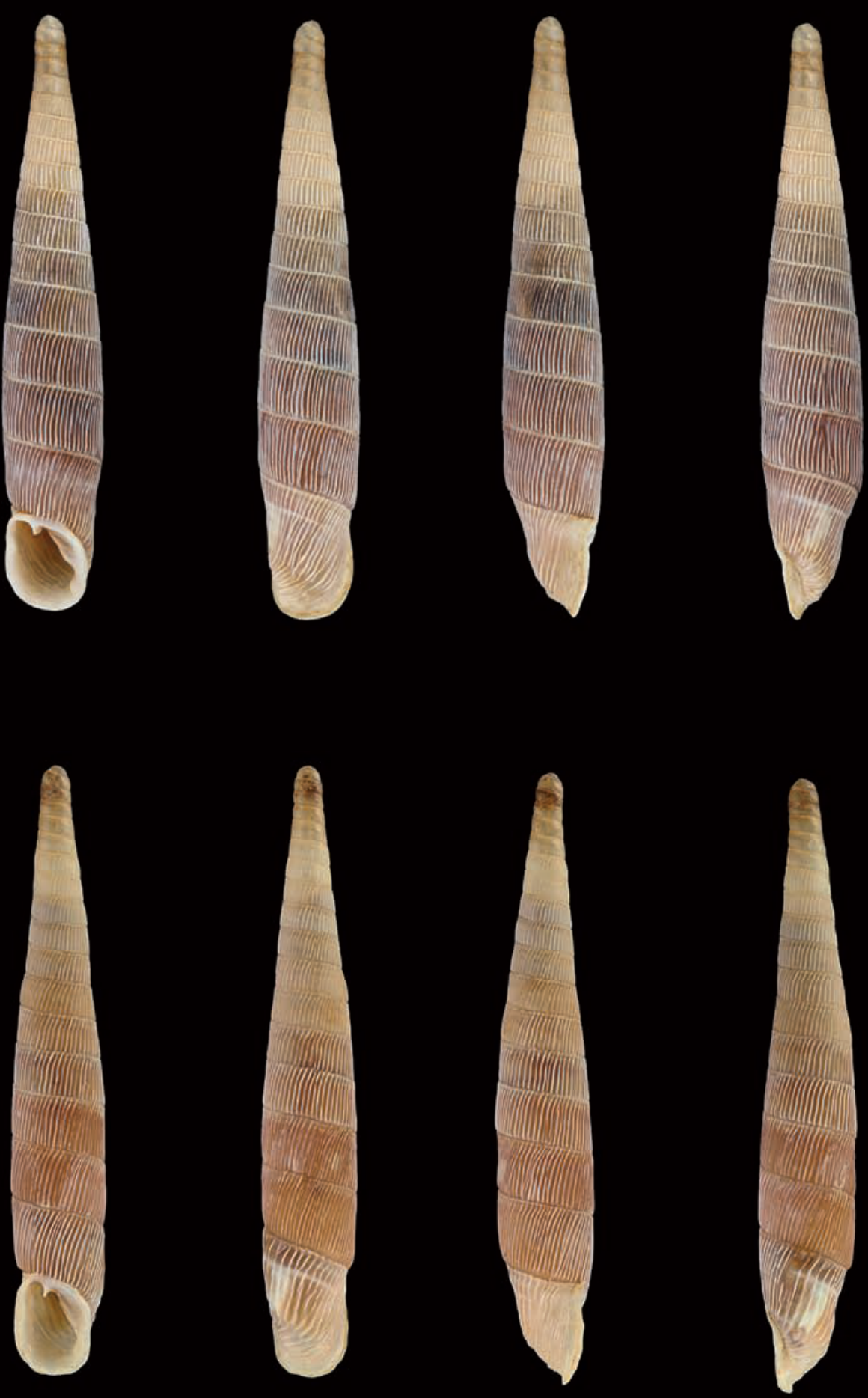

Figure 19. Mauritanica tristrami zribensis n. ssp., Tunisia, Hamman Zriba, holotype, $\mathrm{H}=26 \mathrm{~mm}$. Figure 20. Idem, paratype, $\mathrm{H}=26.5 \mathrm{~mm}$. 


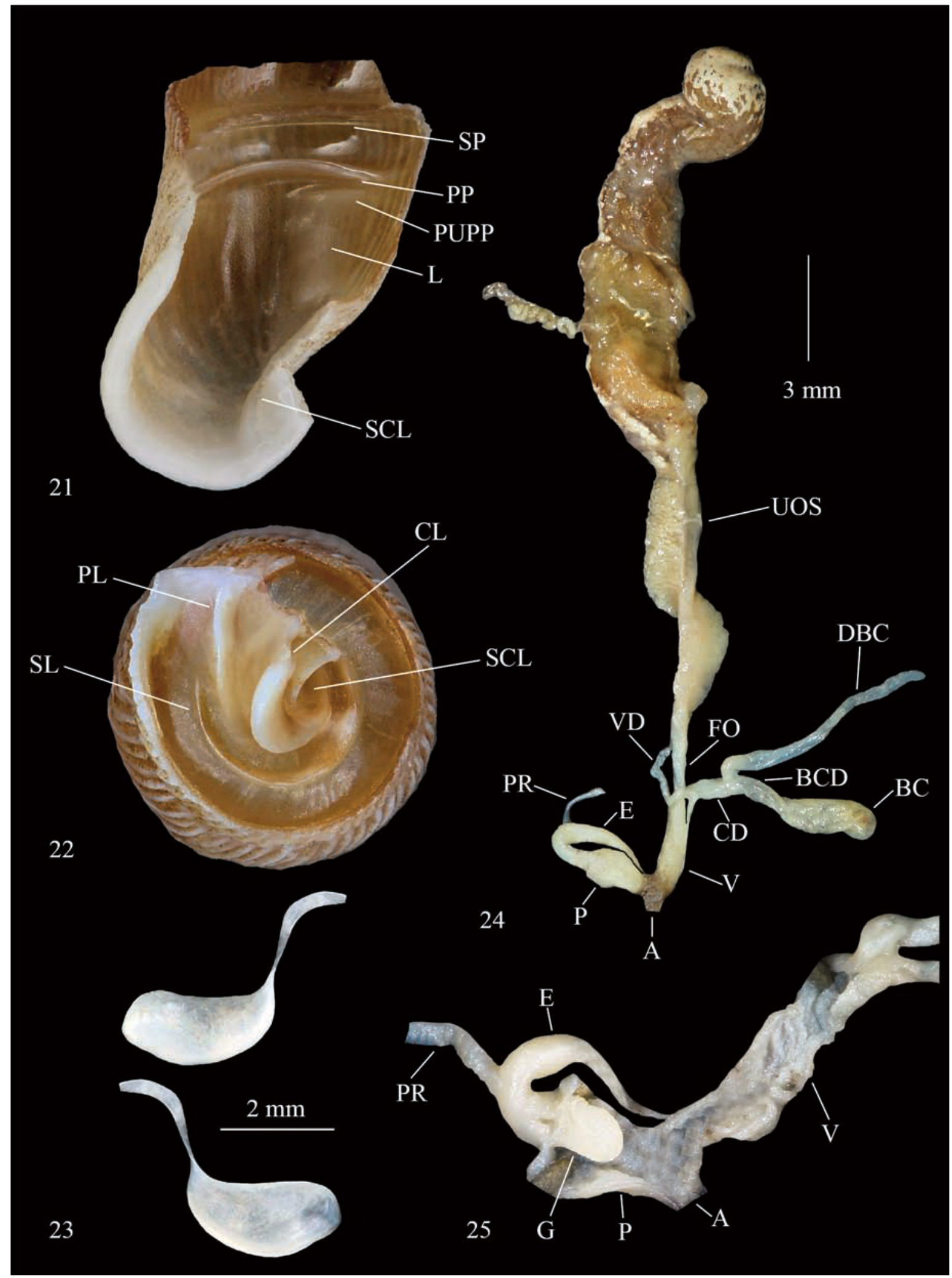

Figures 21-25. Mauritanica tristrami zribensis n. ssp., Tunisia, Hamman Zriba, paratype. Fig. 21: palatum. Fig. 22: parietum. Fig. 23: clausilium. Fig. 24: genitalia. Fig. 25: inner structures of the penis and vagina. 
328

IgNAZIO SPARACIO Et AUI

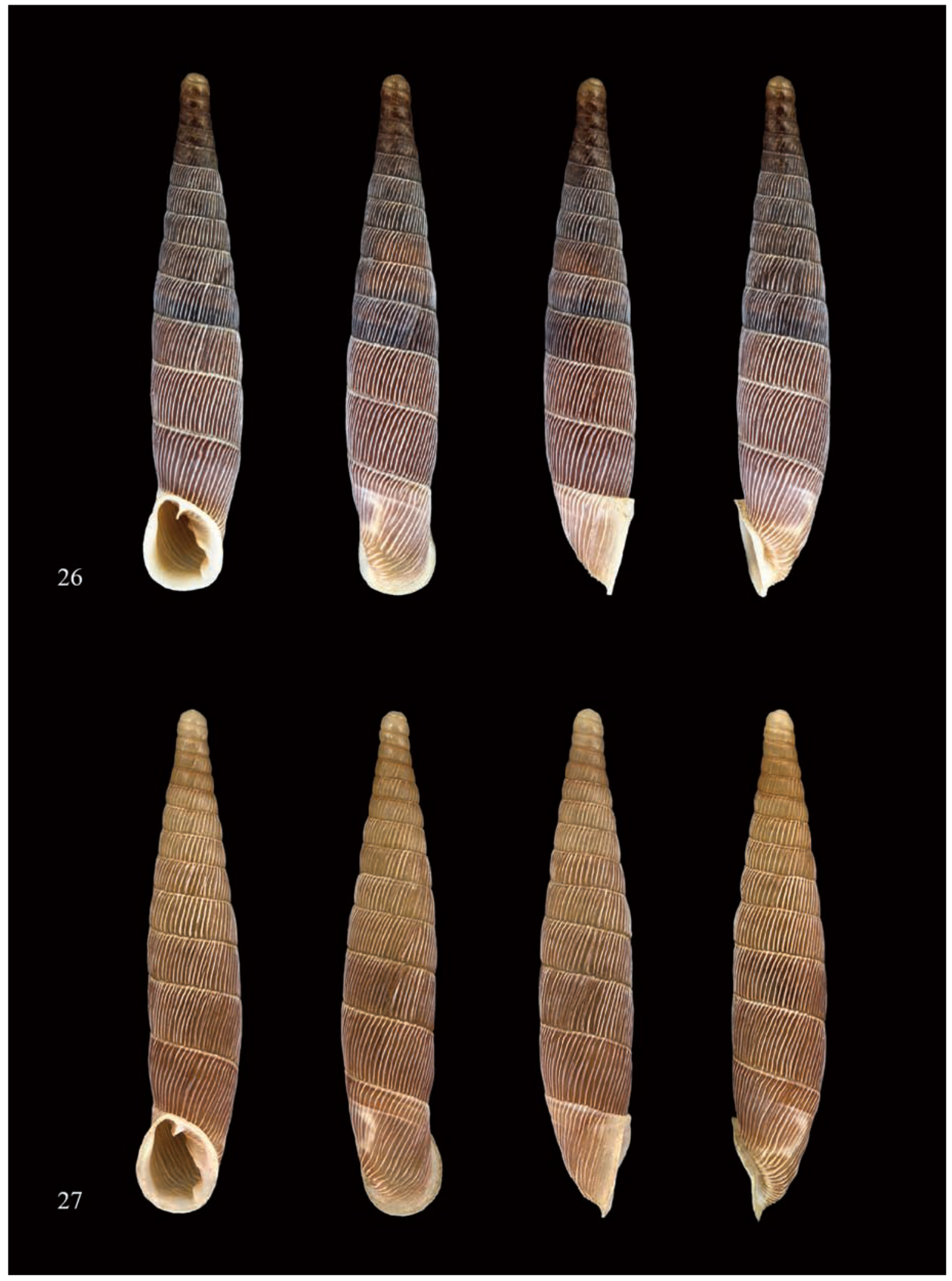

Figure 26. Mauritanica tristrami nouirasaidi n. ssp., Tunisia, Kesra, holotype, $\mathrm{H}=21.3 \mathrm{~mm}$. Figure 27. Idem, paratype, $\mathrm{H}=22.5 \mathrm{~mm}$. 


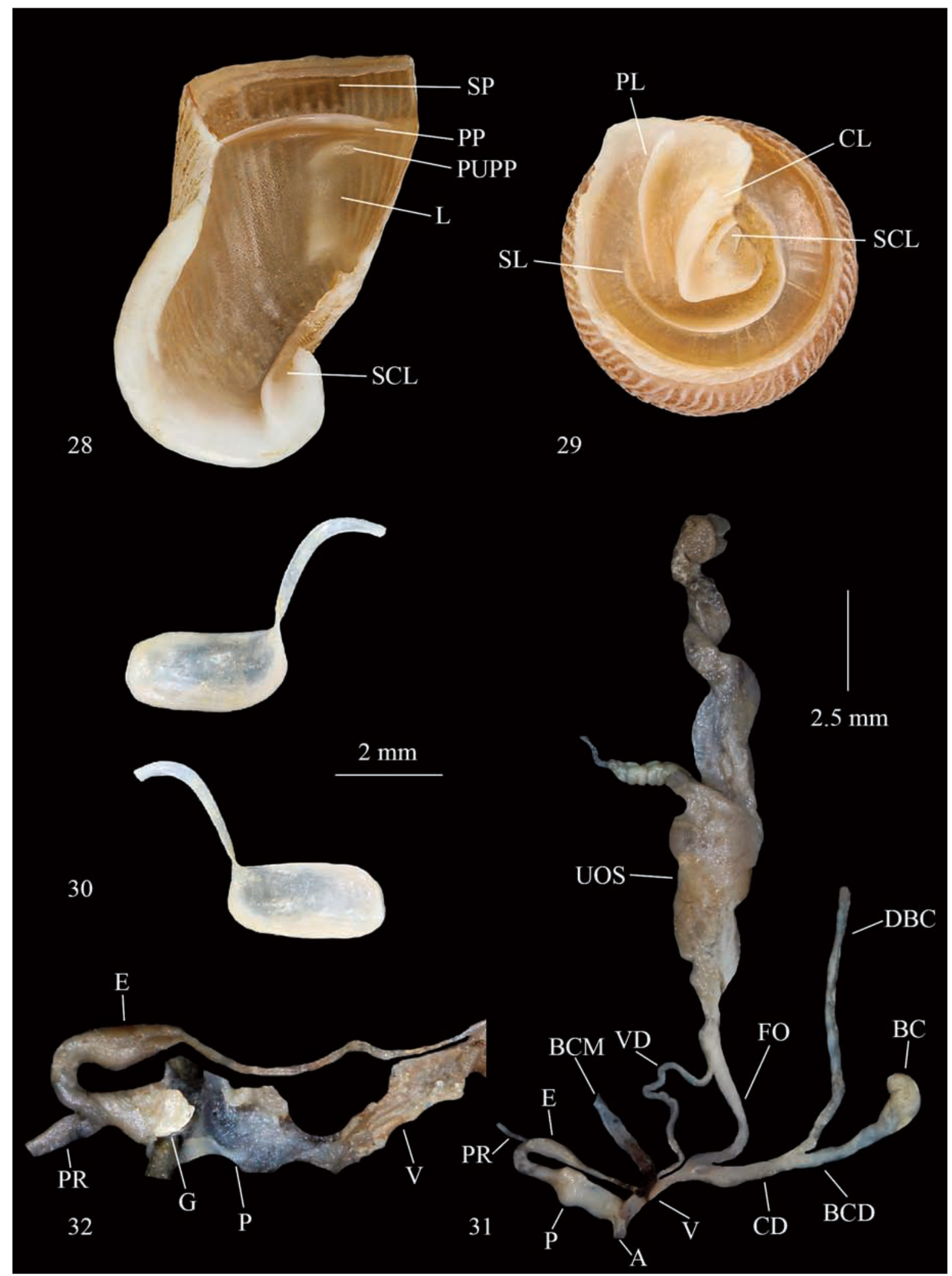

Figures 28-32. Mauritanica tristrami nouirasaidi n. ssp., Tunisia, Kesra, paratype. Fig. 28: palatum. Fig. 29: parietum. Fig. 30: clausilium. Fig. 31: genitalia. Fig. 32: inner structures of the penis and vagina. 


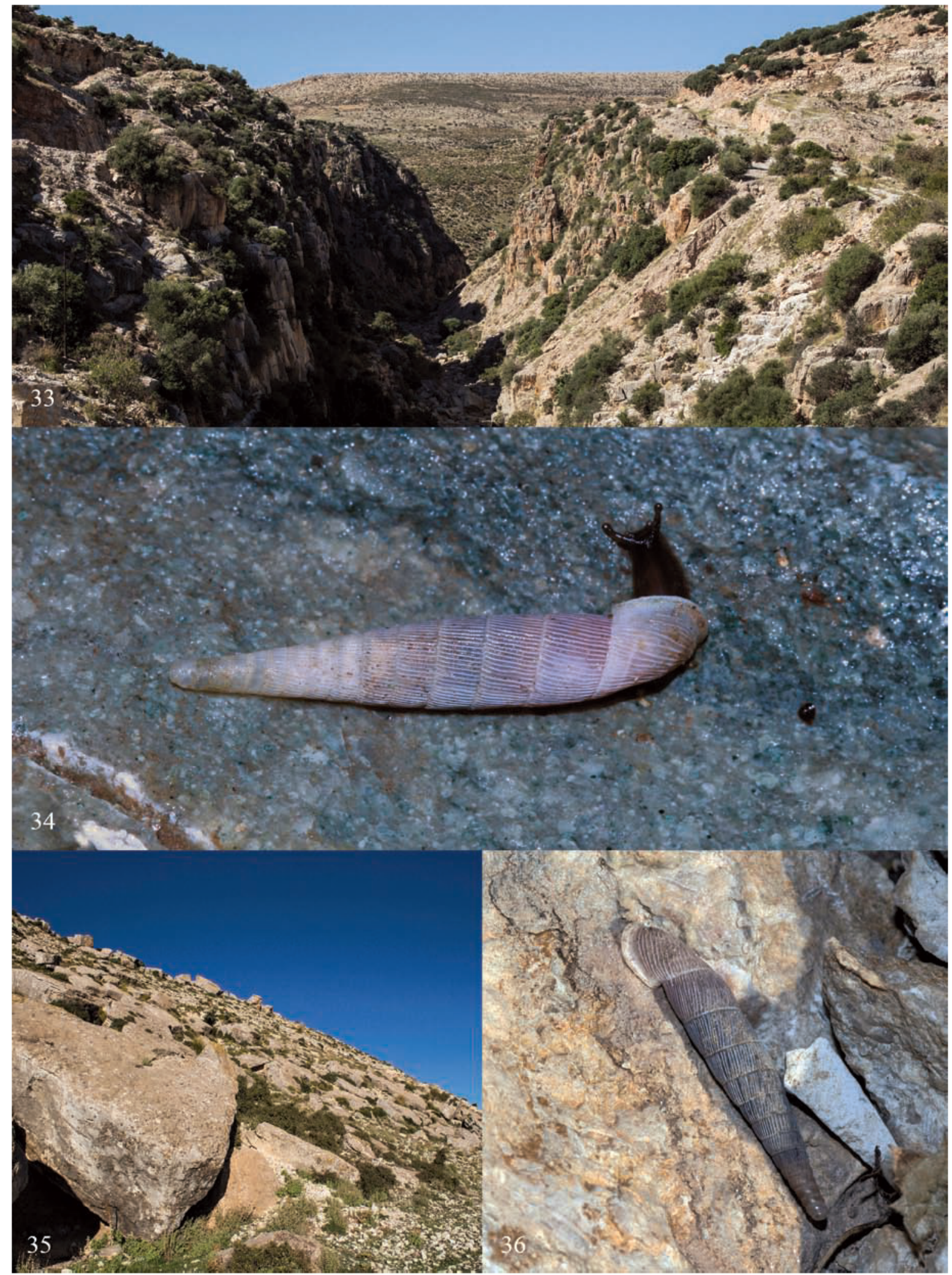

Figure 33. Tunisia, gorge near Hamman Zriba. Figure 34. Mauritanica tristrami zribensis $\mathrm{n}$. ssp. Figure 35. Tunisia, landscape of Kesra. Figure 36. Mauritanica tristrami nouirasaidi $\mathrm{n}$. ssp. 


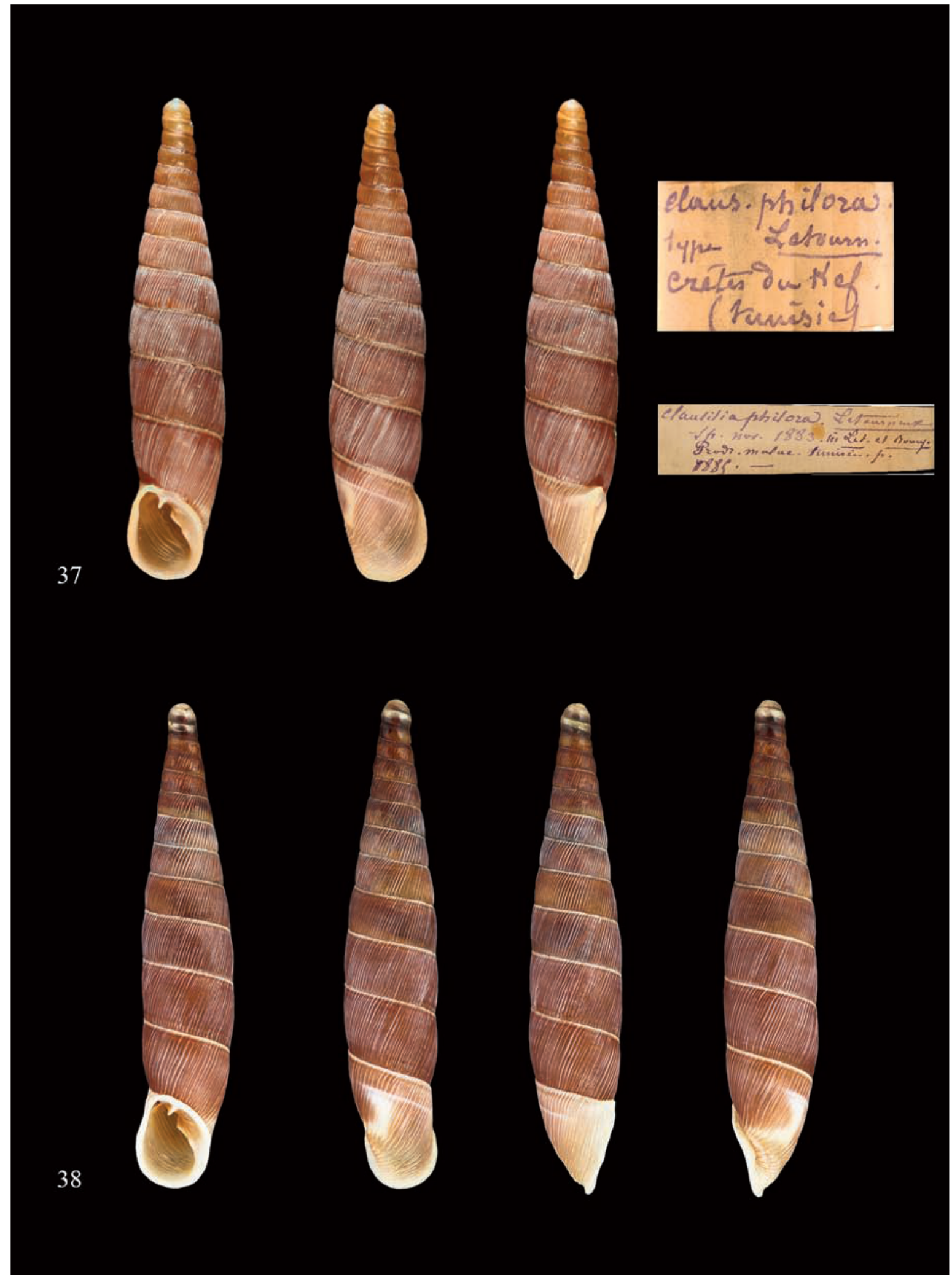

Figure 37. Clausilia philora Letourneux, 1887, Tunisia, El Kef, syntype with original labels. Figure 38. Mauritanica philora philora, Tunisia, El Kef, $\mathrm{H}=22 \mathrm{~mm}$.. 


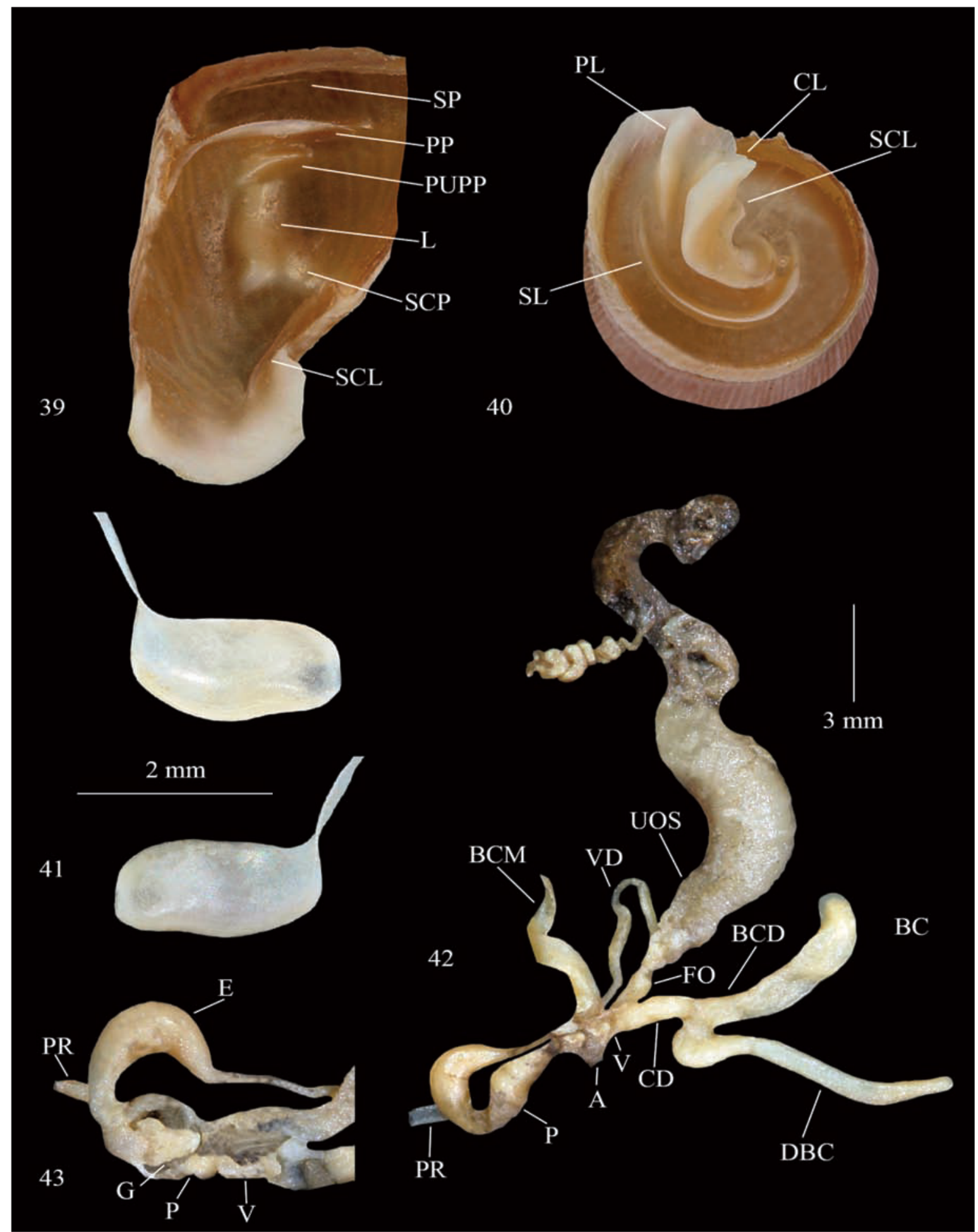

Figures 39-43. Mauritanica philora philora, Tunisia, El Kef. Fig. 39: palatum. Fig. 40: parietum. Fig. 41: clausilium. Fig. 42: genitalia. Fig. 43: inner structures of the penis and vagina. 


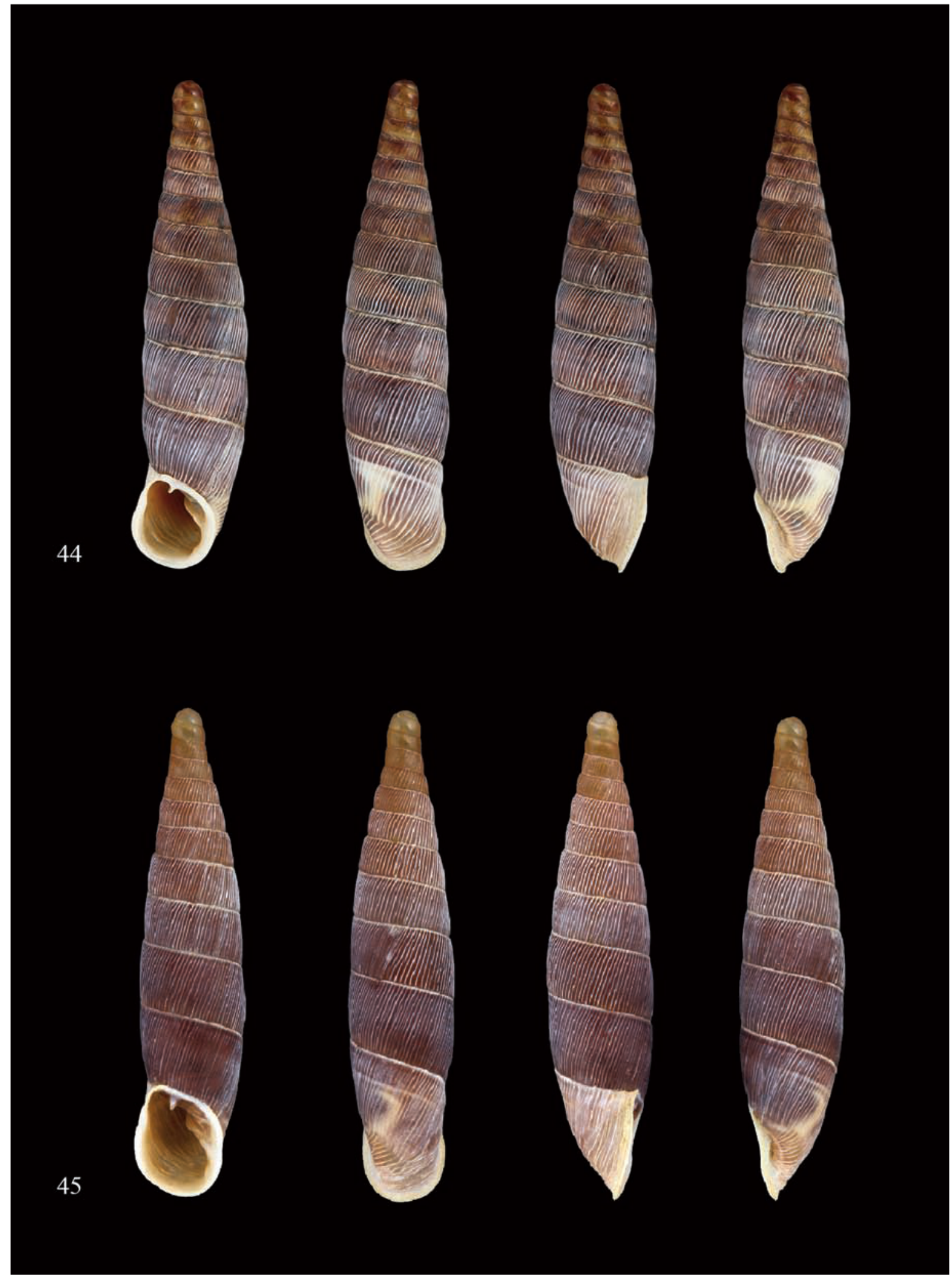

Figure 44. Mauritanica philora bognanni n. ssp., Tunisia, Teboursouk: Dougga, holotype, $\mathrm{H}=21.5 \mathrm{~mm}$. Figure 45. Idem, paratype, Djebba, $\mathrm{H}=20.4 \mathrm{~mm}$. 


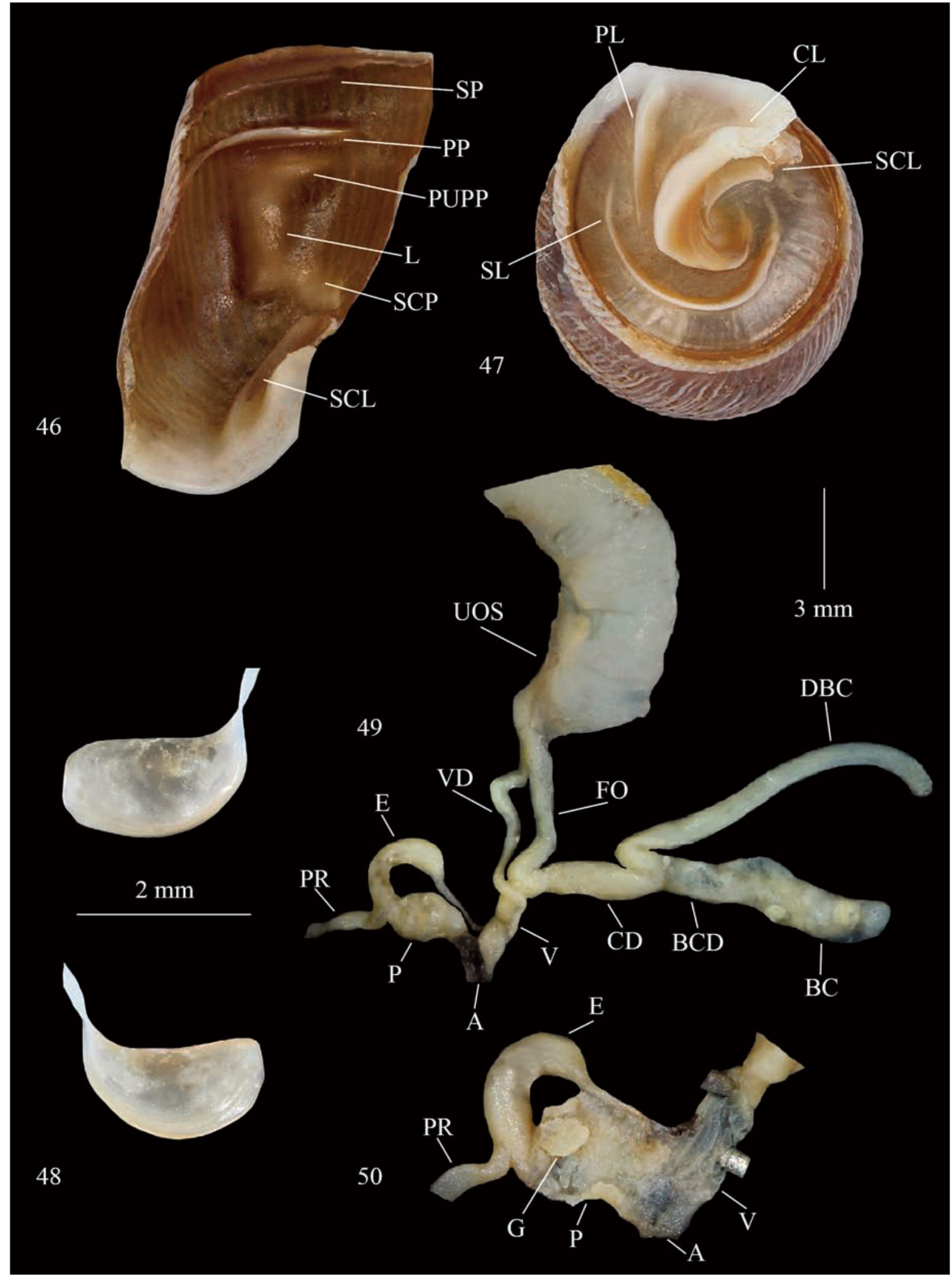

Figures 46-50. Mauritanica philora bognannii n. ssp. from Tunisia, Teboursouk: Dougga, paratype. Fig. 46: palatum. Fig. 47: parietum. Fig. 48: clausilium. Fig. 49: genitalia. Fig. 50: inner structures of the penis and vagina. 


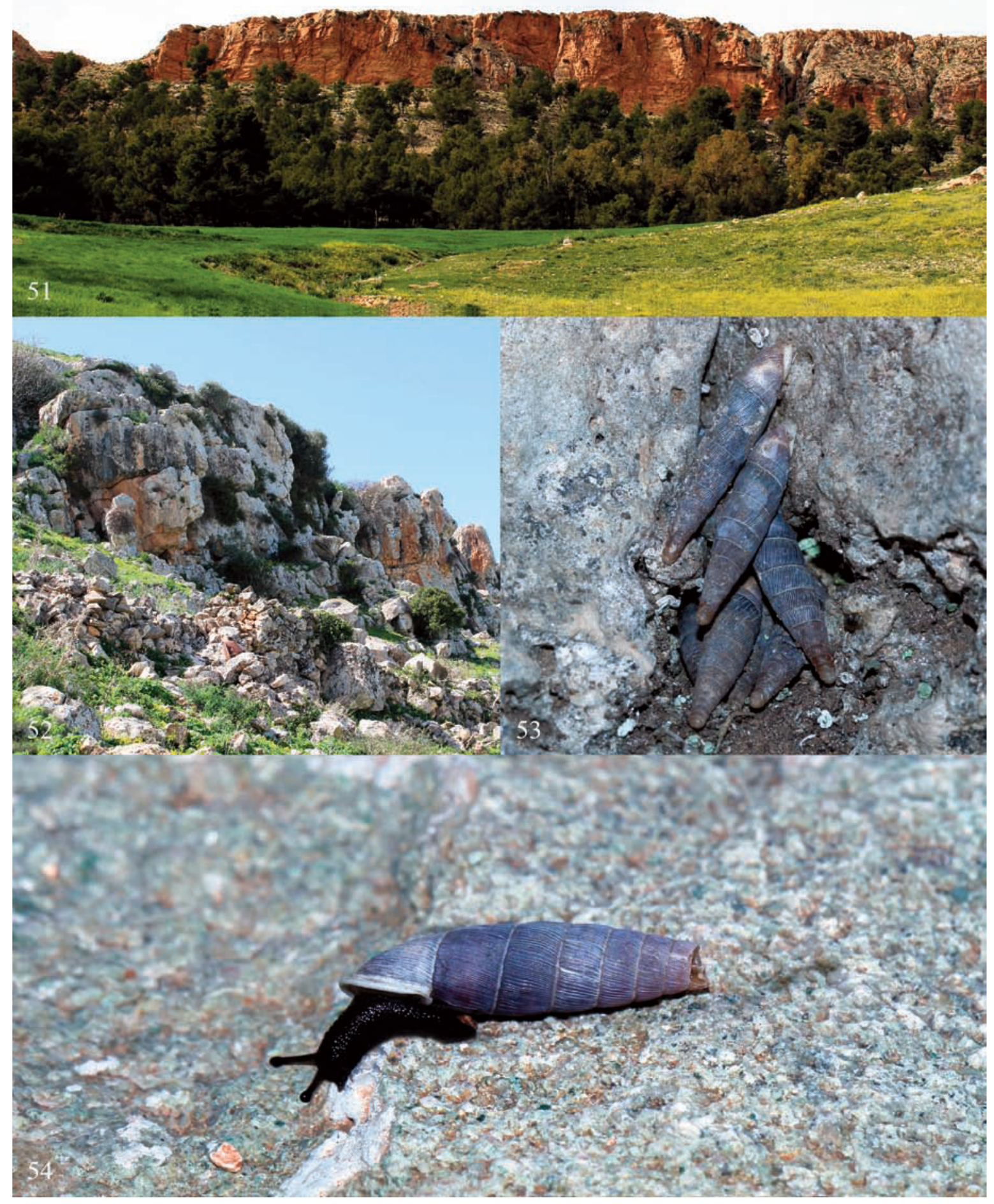

Figure 51. Tunisia, El Kef (“Crêtes du Kef”, see text). Figure 52. Tunisia, Teboursouk, Dougga. Figures 53, 54. Mauritanica philora bognanni n. ssp. 


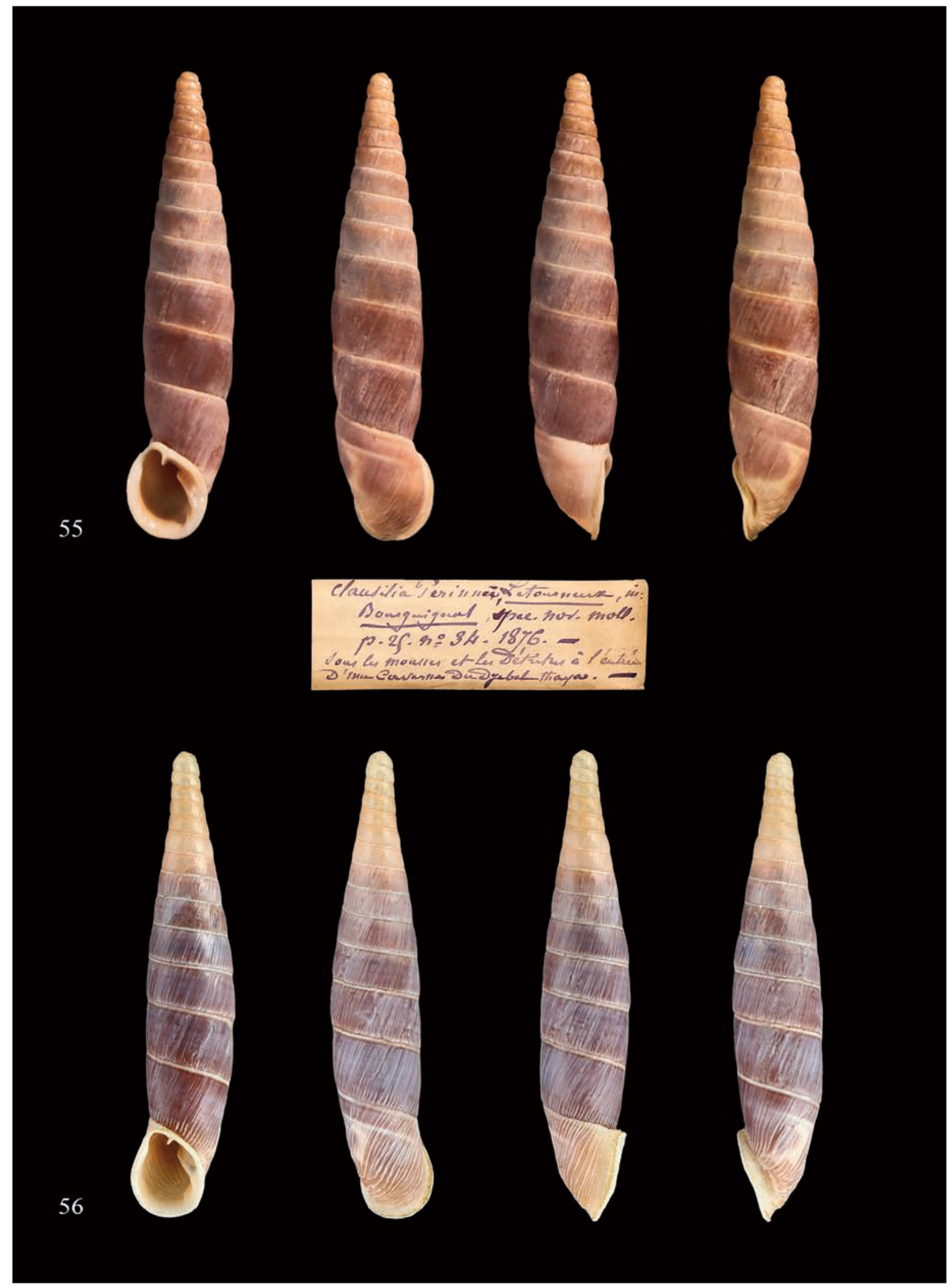

Figure 55. Clausilia perinnei Letourneux, 1876, Algeria, Djebel Thaya, syntype with original label, $\mathrm{H}=24 \mathrm{~mm}$. Figure 56. Mauritanica perinni polygyra,Tunisia, Djebel Zaghouan, $\mathrm{H}=26.8 \mathrm{~mm}$. 


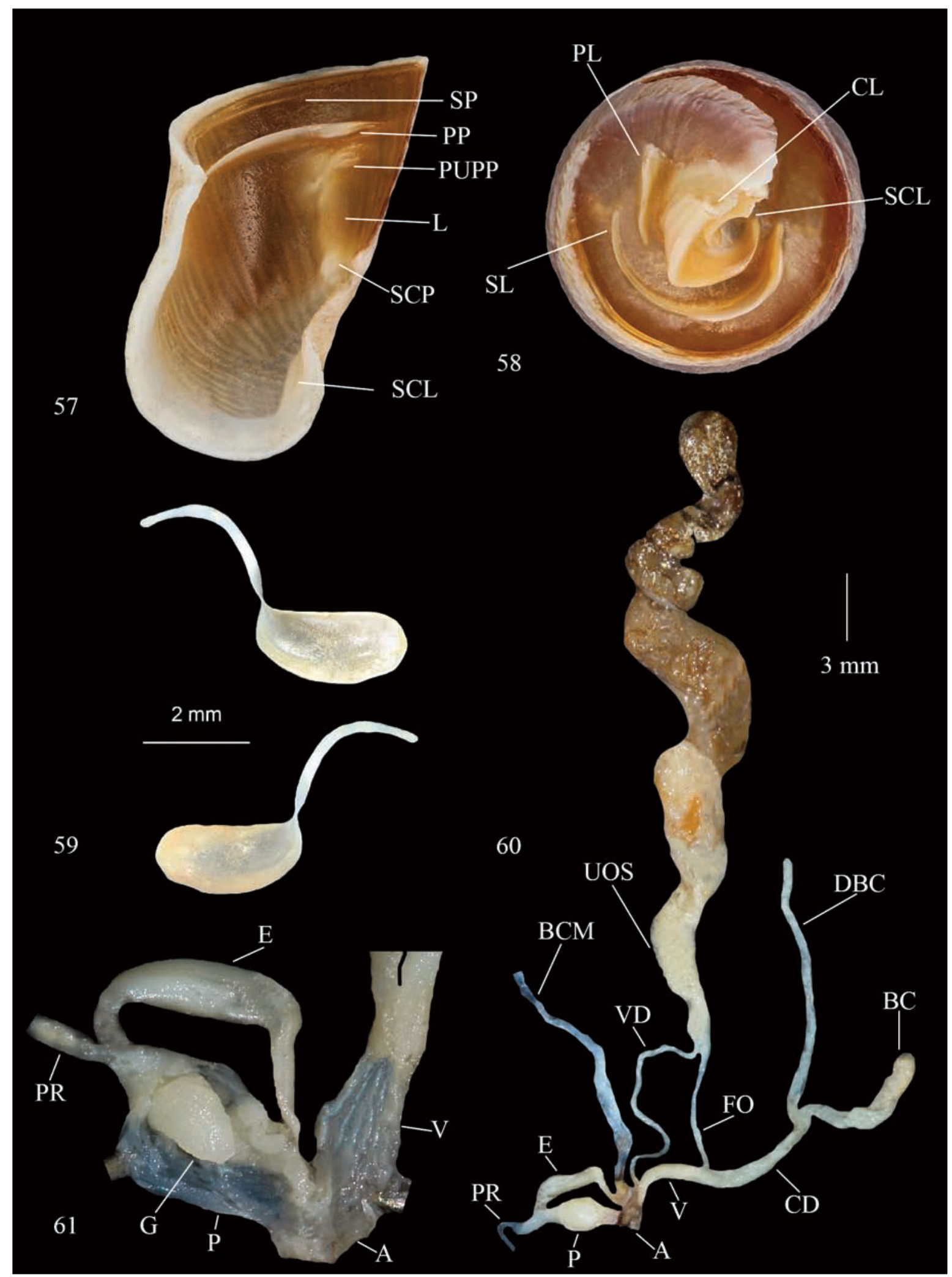

Figures 57-61. Mauritanica perinni polygyra, Tunisia, Djebel Zaghouan. Fig. 57: palatum.

Fig. 58: parietum. Fig. 59: clausilium. Fig. 60: genitalia. Fig. 61: inner structures of the penis and vagina. 


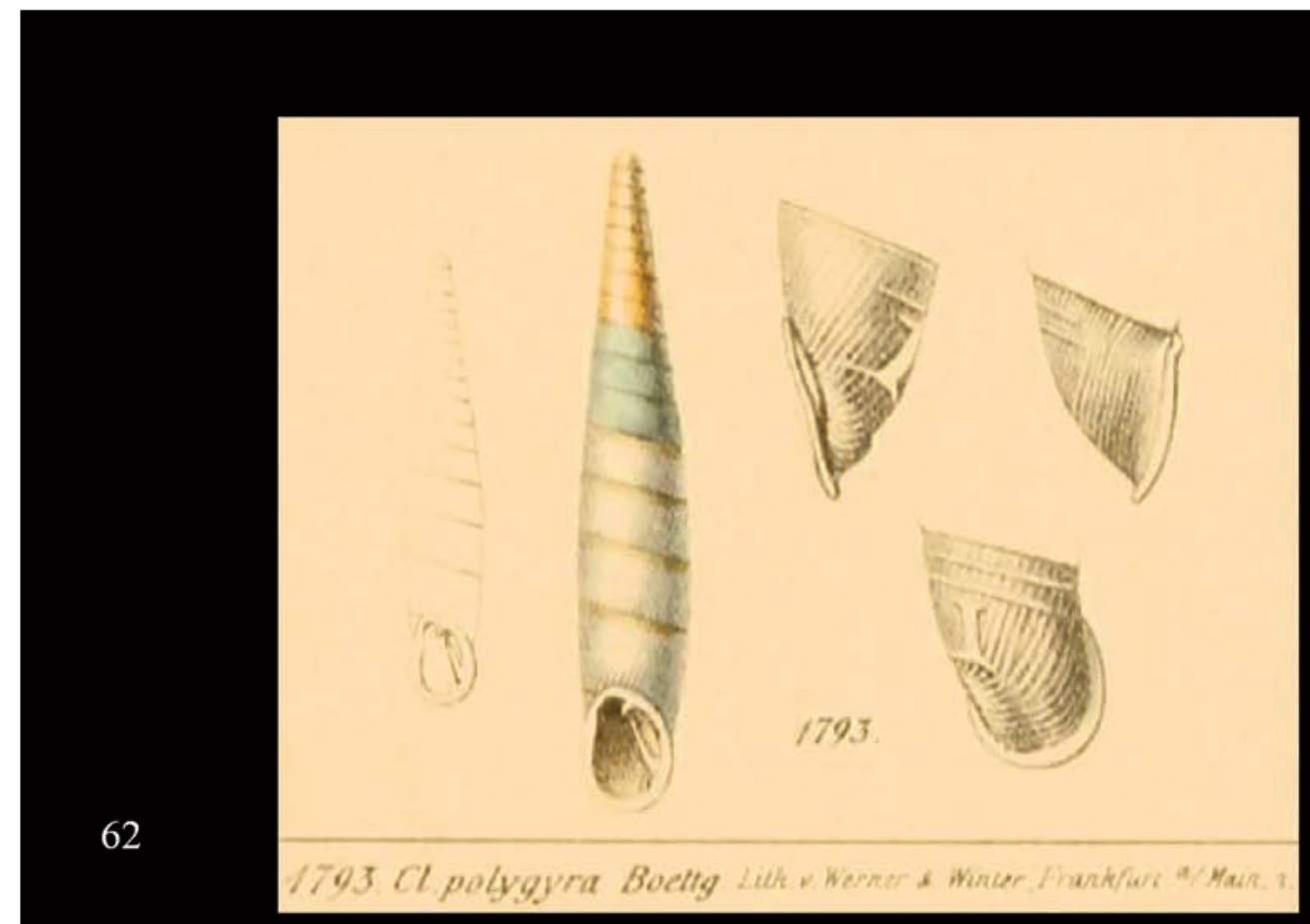

63

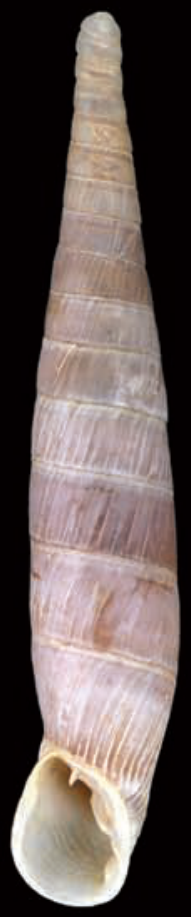

64
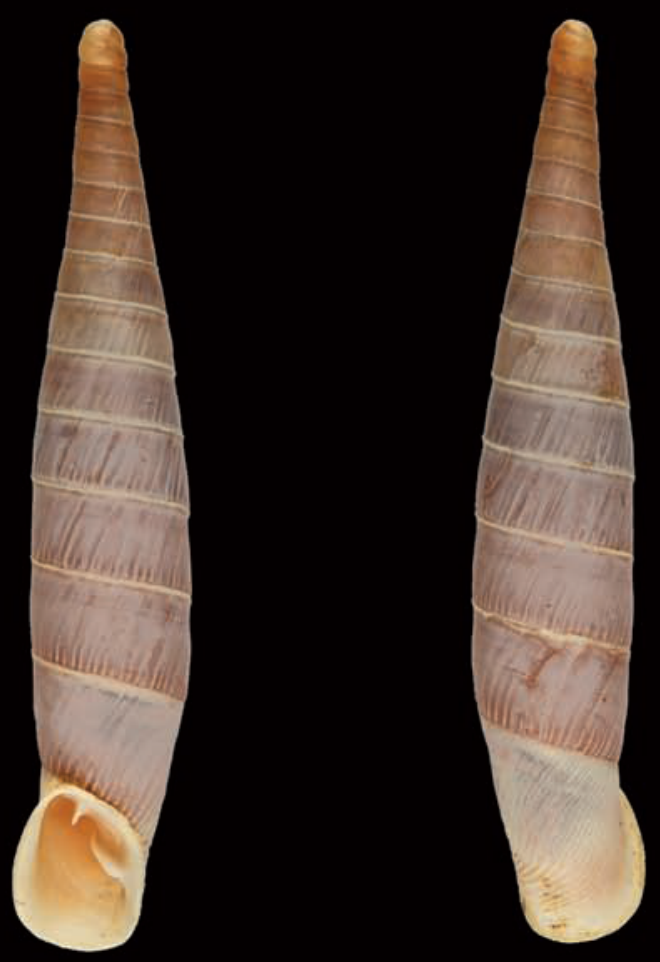

Figure 62. Clausilia polygyra Boettger in Kobelt, 1879: table 177, fig. 1793. Figure 63. Mauritanica perinni polygyra, Tunisia, Djebel Zaghouan, $\mathrm{H}=26.3 \mathrm{~mm}$. Figure 64. Mauritanica perinni zaghouanica, Zaghouan (MZUF), $\mathrm{H}=28.5$ $\mathrm{mm}$ 


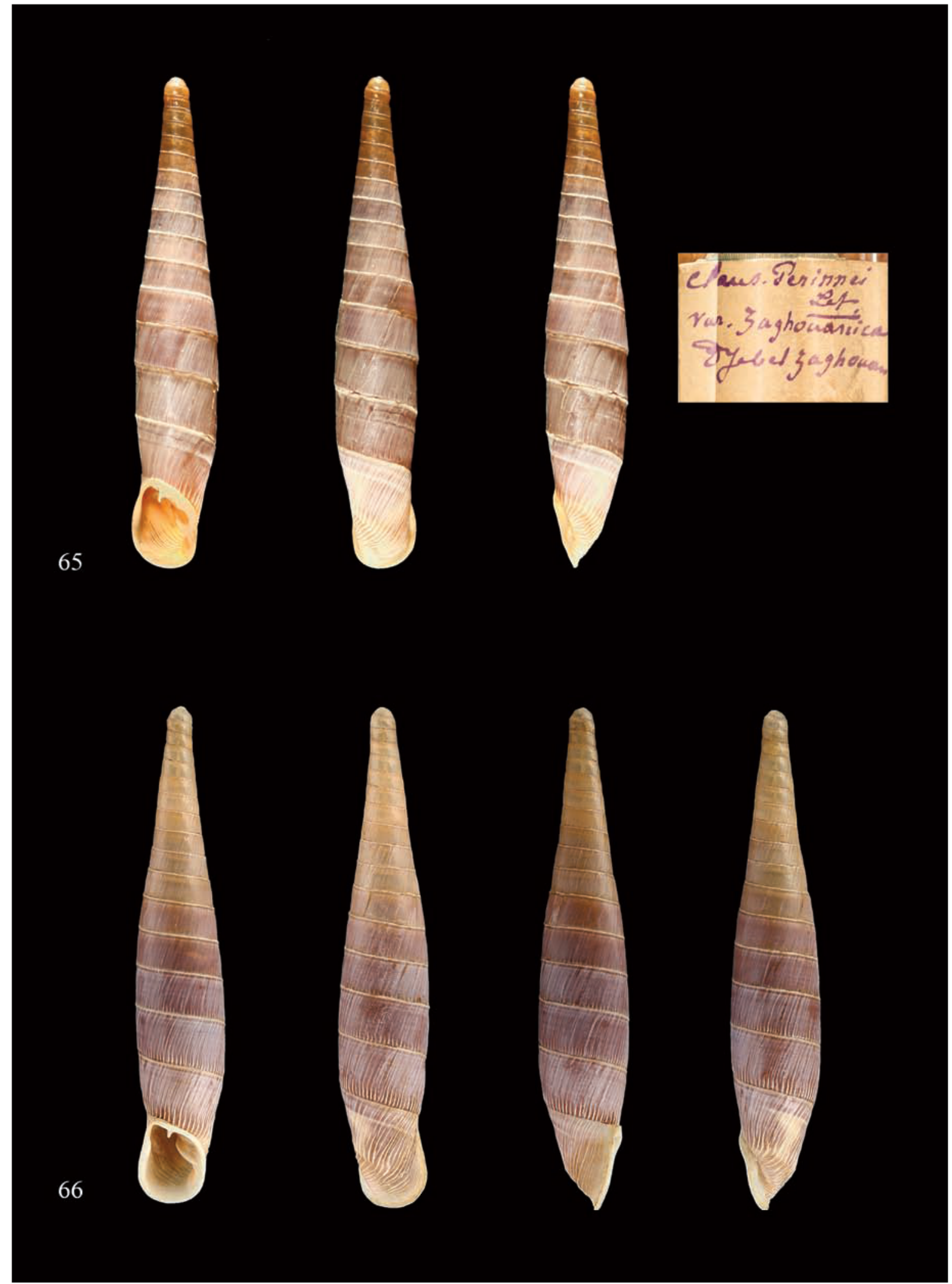

Figure 65. Clausilia perinnei var. zaghouanica Letourneux, 1876, Tunisia, Djebel Zaghouan, syntype with original label, $\mathrm{H}=27.9 \mathrm{~mm}$. Figure 66. Mauritanica perinni zaghouanica, Tunisia, Djebel Zaghouan, $\mathrm{H}=28.2 \mathrm{~mm}$. 


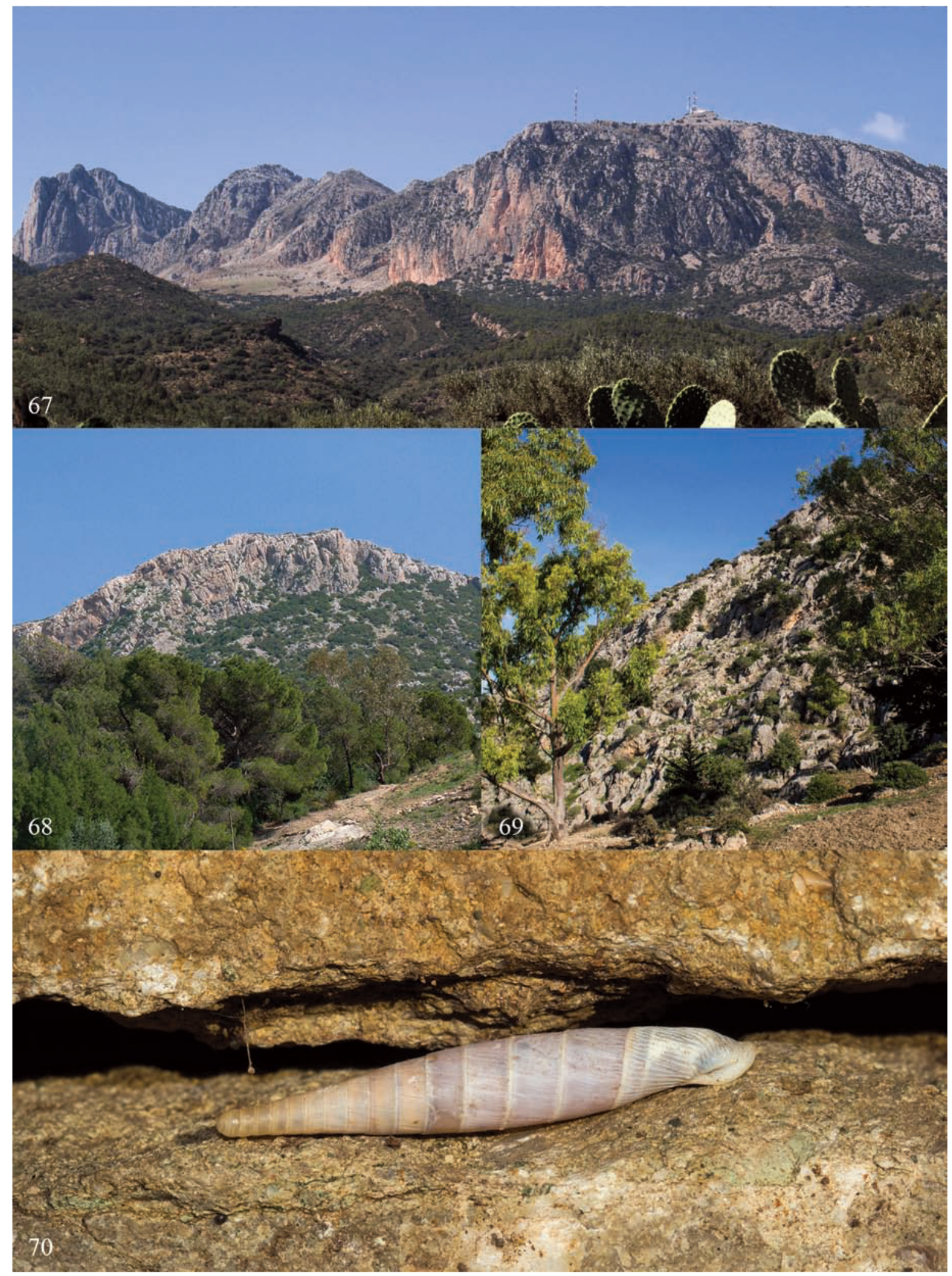

Figure 67. Tunisia, landscape of Djebel Zaghouan. Figures 68, 69. Djebel Zaghouan, SE Zaghouan (see text). Figure 70. Mauritanica perinni polygyra. 


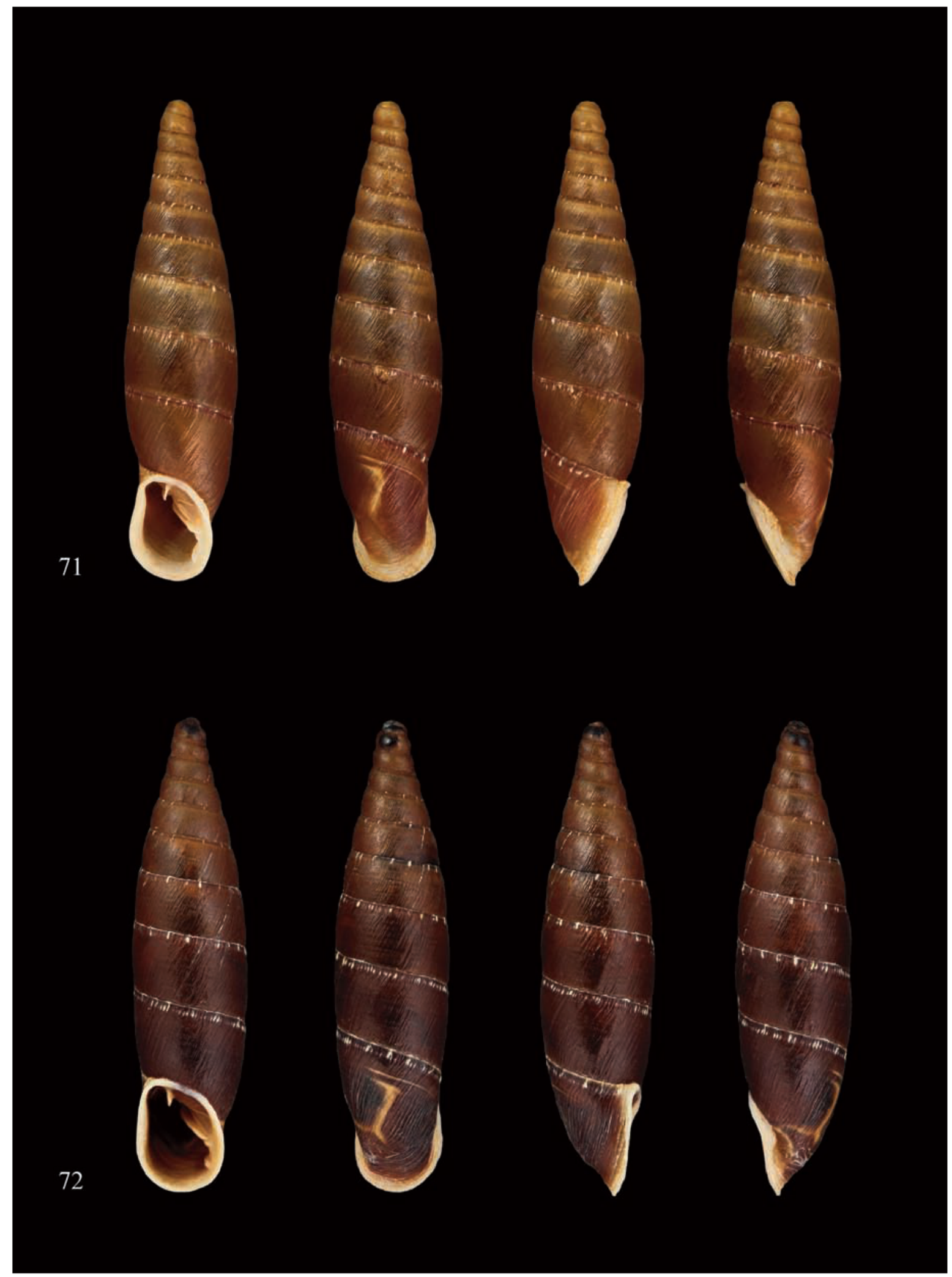

Figure 71. Mauritanica cossonii, Tunisia, Capo Bon, $\mathrm{Al}$ Huwariyah, $\mathrm{H}=17.6 \mathrm{~mm}$. Figure 72. Mauritanica cossonii, Tunisia, Capo Bon, Al Huwariyah, $\mathrm{H}=18.2 \mathrm{~mm}$. 


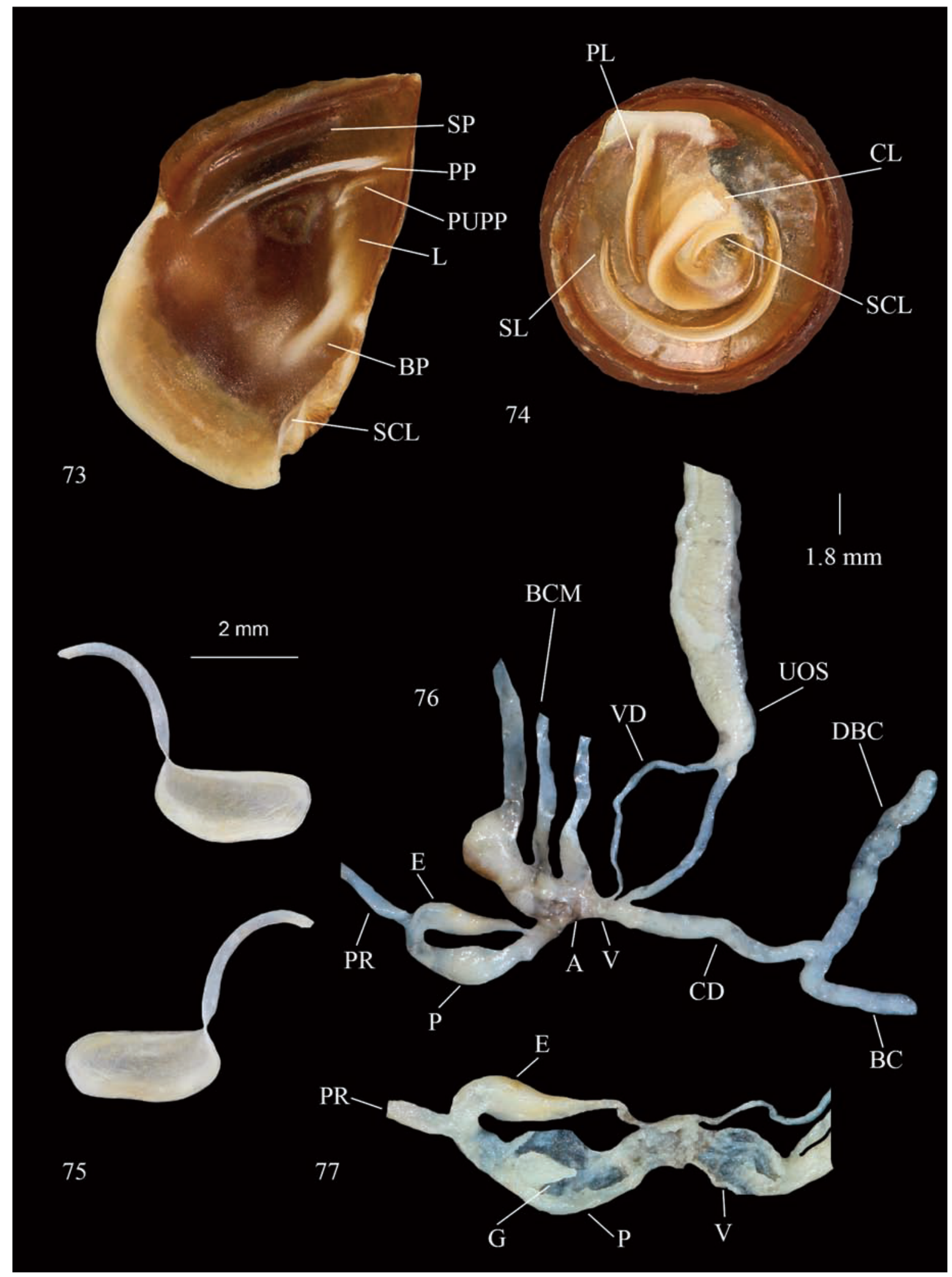

Figures 73-77. Mauritanica cossonii from Tunisia, Capo Bon, Al Huwariyah. Fig. 73: palatum.

Fig. 74: parietum. Fig. 75: clausilium. Fig. 76: genitalia. Fig. 77: inner structures of the penis and vagina. 


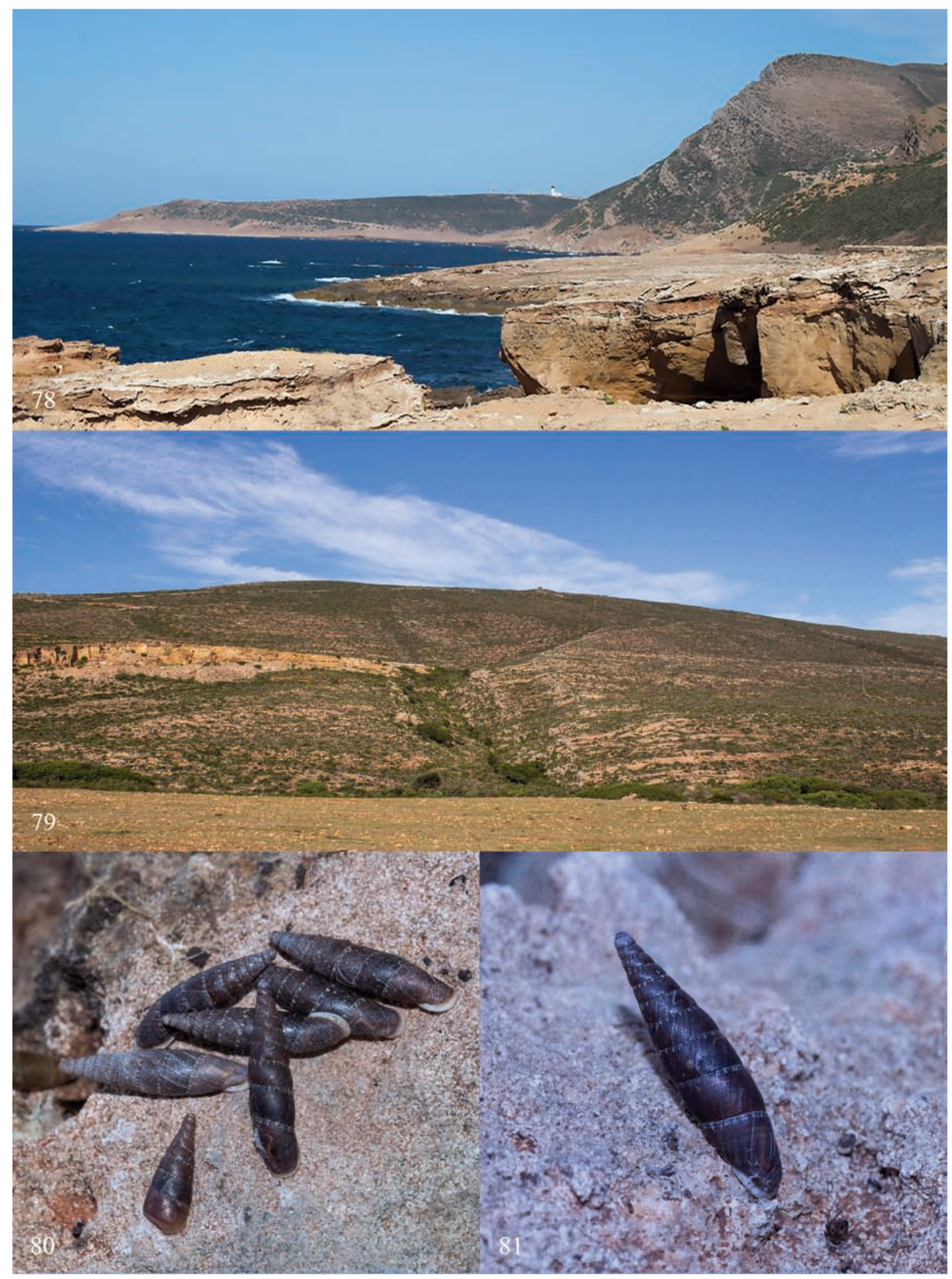

Figure 78. Tunisia, landscape of Capo Bon, northern slope. Figure 79. Tunisia, landscape of Capo Bon, southern slope, near Al Huwariyah; Figures 80, 81. Mauritanica cossonii, under stones. 


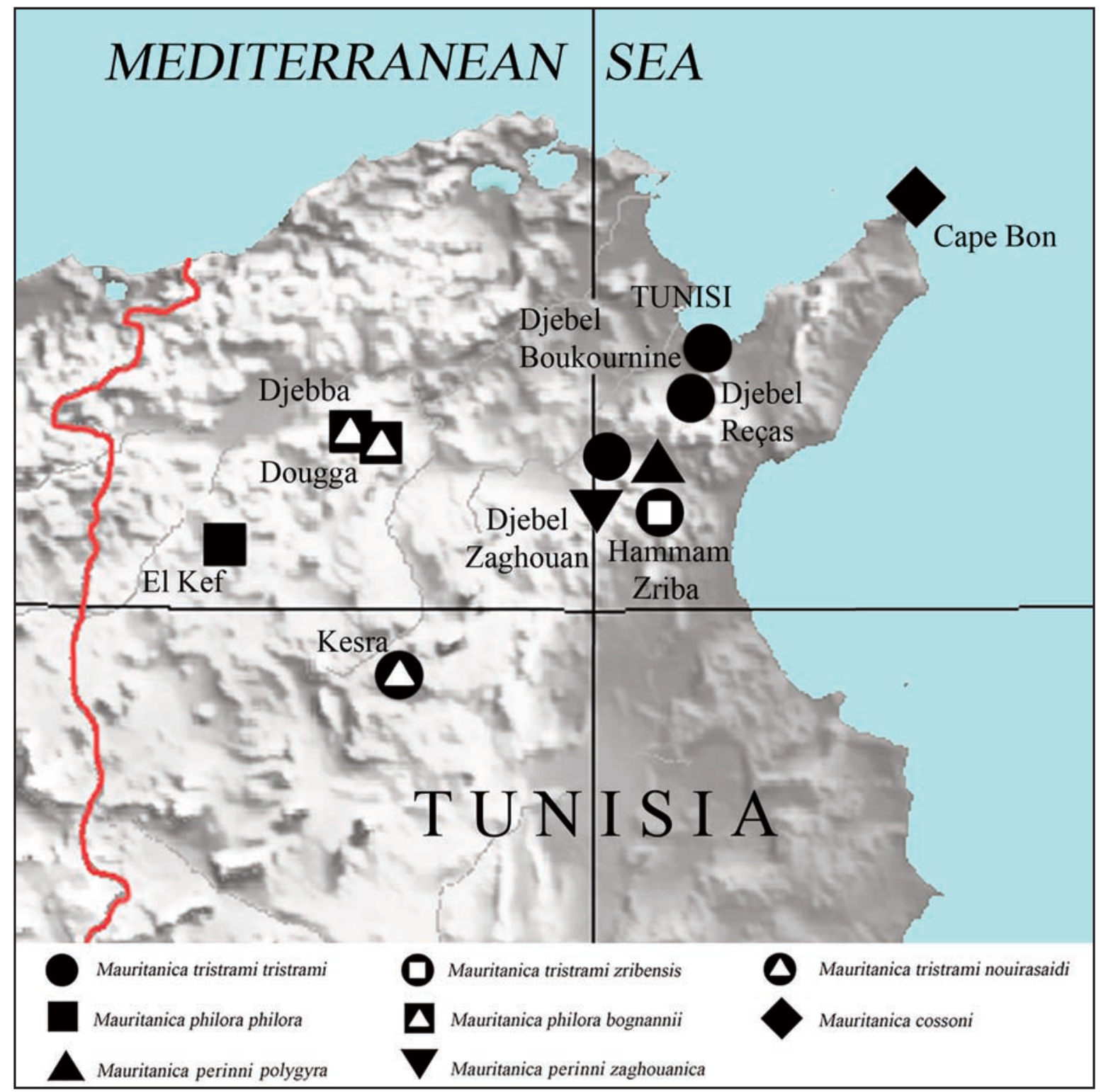

Figure 82. Distribution map of Mauritanica in Tunisia.

\section{ACKNOWLEDGEMENTS}

We thank Massimo Appolloni, Carlo Smriglio and Samantha Zaggia (Museo Civico di Zoologia, Rome, Italy), Estee Bochud, Eike Neubert and Emmanuel Tardy (Muséum d'Histoire Naturelle de Genève, Switzerland), Simone Cianfanelli and Saulo Bambi (Natural History Museum University of Florence Zoological Section "La Specola", Florence, Italy), Saïd Nouira (Département de Biologie, Faculté des Sciences Université de Tunis,
Tunisia), Gianniantonio Domina (Department of Agricultural, Food and Forest Sciences University of Palermo, Italy). We also want to thank Massimo Scalia (Tunis, Tunisia) for the kindness and affection shown to one of us (IS) during his travels in Tunisia.

\section{REFERENCES}

Abbès I., 2012. Gastéropodes terrestres de la Tunisie. Thèses Faculté des Sciences, Université de Tunis, $236 \mathrm{pp}$. 
Bank R.A., 2017. Fauna Europaea. Checklist of the land and freshwater Gastropoda of Europe. Last update: February 2th, 2020

Bank R.A. \& Neubert E., 2019. MolluscaBase. Checklist of land and freshwater Gastropoda of Europe. Last update: February 2th, 2020. Accessed at http:// www.molluscabase.org/

Boettger O., 1879. Gattung Clausilia Drap. In: Rossmässler, Iconographie der Land- \& Süsswasser- Mollusken mit vorzüglicher Berücksichtigung der europäischen noch nicht abgebildeten Arten von E. A. Rossmässler fortgesetzt von Dr. W. Kobelt. Wiesbaden, Kreidel, 6: 52-153, Pl. 167-178.

Bourguignat J.R., 1864. Malacologie de l'Algérie ou histoire naturelle des animaux mollusques terrestres et fluviatiles recueillis jusqu'à ce jour dans nos possessions du nord de l'Afrique. 2: fasc. 4: 1-144, pl. I-V, VII [Jan. 1864]. Challamel ainé, Libraire-Éditeur, Paris, 144 pp.

Bourguignat J.R., 1868. Histoire malacologique de la Régence de Tunis. Challamel Ainé, Paris, 36 pp.

Bourguignat J.R., 1876. Species novissimae Molluscorum in Europaeo systemati detectae, notis diagnosticis succinctis breviter descriptae. Librairie des Sciences Naturelles, Paul Klincksiek, Paris, 80 pp.

Cossignani T., 2014. African landschells. Atlas 3350 colour photos. L'Informatore Piceno, Ancona, 207 pp.

Hagenmüller M., 1884. Clausilie et valvees nouvelles du nord de 1'Afrique. Bulletins de la société Malacologique de France, 1: 209-216

Issel A., 1880. Crociera del Violante, comandato dal capitano armatore Enrico D'Albertis durante 1'anno 1877. I. - Parte narrativa. II. - Cenni sulla geologia della Galita. III. Molluschi terrestri e d'acqua dolce viventi e fossili. R. Istituto Sordo-Muti, Genova, [1], 1-106, Tav. [1-4], 1 map.

Kennard A.S. \& Woodward B.B., 1923. Note on the nomenclature and systematic arrangement of the Clausiliidae. Proceedings of the Malacological Society of London, 15: 298-308.

Ktari M.H. \& Reizig M., 1976. La faune malacologique de la Tunisie septentrionale. Bulletin de la Société des sciences naturelles de Tunisie, 11: 31-74.

Küster H.C., 1847-1867. Die Schliessschnecken und die verwandten Gattungen (Clausilia, Balea, Cylindrella, Megaspira). In: Abbildungen nach der Natur mit Beschreibungen. Systematisches Conchylien-Cabinet von Martini und Chemnitz, 1: 1-355, Pl. 1-38.

Letourneux A. \& Bourguignat J.R., 1887. Prodrome de la malacologie terrestres et fluviatilie de la Tunisie. Exploration scientifique de la Tunisie, zoologie, malacologie. Imprimerie National, Paris, 166 pp.

Lindholm W.A., 1924. A revised systematic list of the genera of the Clausiliidæ, recent and fossil, with their subdivisions, synonymy, and types. Proceedings of the Malacological Society of London, 16: 53-80.

Nordsieck H., 1979. Zur Anatomie und Systematik der Clausilien, XXI. Das System der Clausilien, II: Die rezenten europäischen Clausilien. Archiv für Molluskenkunde, 109: 249-275.

Nordsieck H., 2001. Critical annotations to part 5 (Clausiliidae) of Shileyko's treatise on recent terrestrial pulmonate molluscs (2000) (Gastropoda: Stylommatophora). Mitteilungen der Deutschen Malakozoologischen Gesellschaft, 66: 13-24.

Nordsieck H., 2002. Contributions to the knowledge of the Delimimi (Gastropoda: Stylommatophora: Clausiliidae). Mitteilungen der Deutschen Malakozoologischen Gesellschaft, 67: 27-39.

Nordsieck H., 2007. Worldwide Door Snails (Clausiliidae): Recent and fossil. ConchBooks, Hackenheim, 214 pp.

Nordsieck N., 2013a.. Delimini (Gastropoda, Pulmonata, Clausiliidae) from Apennine Italy, with the description of three new subspecies from Calabria. Conchylia, 44: 3-14.

Nordsieck N., 2013b. Revisory remarks on the species of Siciliaria Vest from N. W. Sicily. Available at.: www.hnords.de/printable/ 5356429d6b11adc0b/5356 42a1dc1365e 05/index.html - last access: 10.4.2019.

Pfeiffer L., 1861. Description of thirty-six new species of Land-shells from Ms. Cuming's collection. Proceedings of the Zoological Society of London, 28: 133-141.

Scheel B.M. \& Hausdorf B., 2012. Survival and differentiation of subspecies of the land snail Charpentieria itala in mountain refuges in the Southern Alps. Molecular Ecology, 21: 3794-3808.

Schileyko A.A., 2000. Treatise on recent terrestrial pulmonate molluscs. Part 5. Clausilliidae. Ruthenica, Suppl. 2: 565-729.

Sparacio I., Liberto F. \& Colomba M.S., 2019. Contributo alla conoscenza di Mauritanica tristrami tristrami (L. Pfeiffer, 1861) in Tunisia (Gastropoda: Stylommatophora: Clausiliidae). Alleryana, 37: 5257.

Tawadros E., 2011. Geology of North Africa. London, CRC Press, $930 \mathrm{pp}$.

Uit de Weerd D.R. \& Gittenberger E., 2013. Phylogeny of the land snail family Clausiliidae (Gastropoda: Pulmonata). Molecular Phylogenetics and Evolution, 67: 201-216.

Wagner A., 1919. Zur Anatomie und Systematik der Clausiliiden. Nachrichtsblatt der Deutschen Malakozoologischen Gesellschaft, 51: 129-147.

Westerlund C.A., 1878. Monografi öfver paläoarktiska regionens Clausilier. Berling, Lund, 1-27, 1-184, 1$12 \mathrm{pp}$. 
Westerlund C.A., 1884. Fauna der in der Palaarktischen Region (Europa, Caukasien, Sibirien, Turan, Persien, Kurdistan, Armenien, Mesopotamien, Kleinasien, Syrien, Arabien, Egypten, Tripolis, Tunesien, Algerien und Marocco) lebenden Binnen-conchylien. Karlskrona, Vol. 4, Gen. Balea Prid. \& Clausilia Drap., vii $+212+18$ pp.

Westerlund C.A., 1890. Katalog der in der paläarctischen
Region lebenden Binnenconchylien. Karlskrona, Johansson, 1-224, [1], 1-128, 1-8 pp.

Westerlund C.A., 1901. Synopsis molluscorum in regione palaearctica viventium ex typo Clausilia Drap. - Zapiski Imperatorskoj Akademii Nauk po fizikomatematicheskomu Otdeleniyu - Mémoires de l'Académie Impériale des Sciences de St. Pétersbourg, Classe physico-mathématique 11: [1, 2], [1-37], 1-203. 